Atmos. Chem. Phys., 18, 10219-10236, 2018

https://doi.org/10.5194/acp-18-10219-2018

(C) Author(s) 2018. This work is distributed under

the Creative Commons Attribution 4.0 License.

\title{
Assessment of wood burning versus fossil fuel contribution to wintertime black carbon and carbon monoxide concentrations in Athens, Greece
}

\author{
Athina-Cerise Kalogridis ${ }^{1}$, Stergios Vratolis ${ }^{1}$, Eleni Liakakou ${ }^{2}$, Evangelos Gerasopoulos $^{2}$, Nikolaos Mihalopoulos ${ }^{2}$, \\ and Konstantinos Eleftheriadis ${ }^{1}$ \\ ${ }^{1}$ Institute of Nuclear \& Radiological Sciences \& Technology, Energy \& Safety, National Centre of Scientific Research \\ "Demokritos", Ag. Paraskevi, 15310, Greece \\ ${ }^{2}$ Institute for Environmental Research and Sustainable Development, National Observatory of Athens, \\ Metaxa \& V. Pavlou, P. Penteli, 15236, Athens, Greece
}

Correspondence: Athina-Cerise Kalogridis (akalogridi@ipta.demokritos.gr)

Received: 11 September 2017 - Discussion started: 16 November 2017

Revised: 1 June 2018 - Accepted: 15 June 2018 - Published: 18 July 2018

\begin{abstract}
The scope of this study was to estimate the contribution of fossil fuel and wood burning combustion to black carbon $(\mathrm{BC})$ and carbon monoxide (CO) during wintertime, in Athens. For that purpose, in situ measurements of equivalent black carbon (eBC) and $\mathrm{CO}$ were simultaneously conducted in a suburban and an urban background monitoring site in Athens during the 3 months of winter 2014-2015. For the deconvolution of $\mathrm{eBC}$ into $\mathrm{eBC}$ emitted from fossil fuel $\left(\mathrm{BC}_{\mathrm{ff}}\right)$ and wood burning $\left(\mathrm{BC}_{\mathrm{wb}}\right)$, a method based on the spectral dependency of the absorption of pure black carbon and brown carbon was used. Thereafter, $\mathrm{BC}_{\mathrm{wb}}$ and $\mathrm{BC}_{\mathrm{ff}}$ estimated fractions were used along with measured $\mathrm{CO}$ concentrations in a multiple regression analysis, in order to quantify the contribution of each one of the combustion sources to the ambient CO levels. For a comparative analysis of the results, we additionally estimated the wood burning and fossil fuel contribution to $\mathrm{CO}$, calculated on the basis of their $\mathrm{CO} / \mathrm{NO}_{x}$ emission ratios. The results indicate that during wintertime $\mathrm{BC}$ and $\mathrm{CO}$ are mainly emitted by local sources within the Athens Metropolitan Area (AMA). Fossil fuel combustion, mainly from road traffic, is found to be the major contributor to both $\mathrm{eBC}$ in $\mathrm{PM}_{2.5}$ and $\mathrm{CO}$ ambient concentrations in AMA. However, wintertime wood burning makes a significant contribution to the observed eBC (of about $30 \%$ ) and $\mathrm{CO}$ concentrations (on average, 11 and $16 \%$ of total $\mathrm{CO}$ in the suburban and urban background sites respectively). Both $\mathrm{BC}$ and $\mathrm{CO}$ from biomass burning $\left(\mathrm{BC}_{\mathrm{wb}}\right.$ and $\mathrm{CO}_{\mathrm{wb}}$, respectively) present a clear diurnal pattern, with the highest con-
\end{abstract}

centrations during night-time, supporting the theory of local domestic heating being their main source.

\section{Introduction}

Air pollution, which originates largely from combustion processes, is a very important environmental concern in Athens, like in other large urban agglomerations around the world. A high population (3.75 million in the metropolitan area) and the confinement of commercial and industrial activities to a relatively small area (approximately $450 \mathrm{~km}^{2}$ ), has led to severe environmental degradation. Over the years high loadings of atmospheric pollutants have been documented (Chaloulakou et al., 2005; Eleftheriadis et al., 1998, 2014; Kalabokas et al., 1999; Theodosi et al., 2011). Combustion processes used for transportation, power generation and other human activities produce a complex mixture of chemical pollutants (Cohen et al., 2004), which at any given location have characteristics depending on the relative contributions of the different sources of pollution and on the effects of the local geo-climatic factors. Black carbon (BC) aerosol and carbon monoxide $(\mathrm{CO})$ are two major products of incomplete combustion and are important atmospheric components because of their substantial impact on health (Ostro et al., 2015), including respiratory and cardiovascular effects, as well as on climate (Zanatta et al., 2016). BC refers to the absorb- 
ing components of soot and is the second most significant contributor to climate change (Andreae and Gelencsér, 2006; Bond et al., 2013). CO strongly influences the oxidative capacity of the atmosphere (by reacting with the $\mathrm{OH}$ radicals) and thereby alters the lifetime of methane and other greenhouse gases (Seinfeld and Pandis, 2012). The potential adverse health and climate effects, associated with exposure to high levels of $\mathrm{BC}$ and $\mathrm{CO}$, motivates a thorough characterization of their emission from different sources. In urban environments, fossil fuel combustion is the major source of $\mathrm{BC}$ and $\mathrm{CO}$, mainly related to motor vehicle exhausts. However, biomass combustion, from forest fires (especially in summer; Diapouli et al., 2014) or from domestic heating (in winter), may also contribute significantly to their ambient levels.

Improvement of air quality in Athens after measures adopted during recent decades are described by Kanakidou et al. (2011) and are in line with proposed mitigation strategies (Aleksandropoulou et al., 2012). Vrekoussis et al. (2013) used satellite observations of $\mathrm{NO}_{2}$ and $\mathrm{SO}_{2}$ over Athens, to show that the economic crisis resulted in acceleration of the reduction of air pollutants in Athens. In the recent years, a resurgence in the use of biofuels over more expensive fuels for heating has been observed in Europe (Denier van der Gon et al., 2015; Gonçalves et al., 2011), especially in Greece where the economic crisis has tripled the fossil fuel cost in a few years (Saffari et al., 2013). The technology of domestic wood burning in Athens is known to suffer from low burning efficiency. The extensive use of wood burning observed in recent years resulted in considerable emissions from incomplete combustion, i.e. $\mathrm{CO}$, hydrocarbons and soot particles during cold months. Paraskevopoulou et al. (2015), reported the impact of wood combustion (dominant fuel for domestic heating) on air quality in Athens, as an almost $30 \%$ increase in the contribution of particulate organic matter to the urban aerosol mass, from winter 2012 to winter 2013. At the same time, a long-term analysis of elemental carbon (EC) concentrations in Athens (Paraskevopoulou et al., 2014) revealed a significant increase in wintertime EC in the period 2011-2013. A significant increase in winter evening $\mathrm{CO}$ level has been reported for the period 2012-2015 by Gratsea et al. (2017) and attributed to the increase in wood burning use. By contrast, during summertime a consistent decrease was encountered in the last decade as a result of the simultaneous reduction in traffic and industrial activity due to the economic crisis in Greece (Diapouli et al., 2017a).

Even though biomass burning from domestic heating has been recognized as one of the main sources of atmospheric pollutants in southern Europe (Denier van der Gon et al., 2015; Giannoni et al., 2012; Gonçalves et al., 2011; Paglione et al., 2014; Saffari et al., 2013), emission estimates are still scarce and the associated uncertainty remains high. This is because wood consumption statistics are difficult to obtain since wood is often non-commercial and emission factors vary greatly with wood type, combustion equipment and flame temperature. As a matter of fact, reported emission factors of PM for different types of residential combustion appliances range between 10 and $2000 \mathrm{mg} \mathrm{MJ}^{-1}$ of fuel burnt (Kocbach Bølling et al., 2009). In a similar way, $\mathrm{CO}$ emission factors from fireplaces and traditional or ecolabelled woodstoves range typically from 30 to $120 \mathrm{~g} \mathrm{~kg}^{-1}$ (ratio of the mass of $\mathrm{CO}$ emitted to the mass of the burnt fuel) (AIRUSE, 2015). The spatial variability of the carbonaceous aerosol pollutants is also of great interest with respect to the health impacts of their major contributing sources in the urban $\mathrm{PM}_{10}$.

In this context, the scope of the present study is to investigate, based on ambient measurements, the impact of biomass burning versus fossil fuel use on the air pollution observed in Athens during wintertime. For that purpose, 3 months of continuous and simultaneous measurements of equivalent black carbon (eBC) by Aethalometers and $\mathrm{CO}$ at a suburban and an urban background site of Athens were analysed and compared. The measured eBC was deconvoluted into two fractions using a model based on the different spectral dependencies of light absorption by pure black carbon (related to fossil fuel) and brown carbon (linked to wood burning emissions) (Sandradewi et al., 2008). For simplicity we refer to these light-absorbing carbon fractions as "BC" with an additional index for specifying the wood burning $\left(\mathrm{BC}_{\mathrm{wb}}\right)$ or fossil fuel $\left(\mathrm{BC}_{\mathrm{ff}}\right)$ origin. A new approach based on the relations between $\mathrm{CO}, \mathrm{BC}_{\mathrm{wb}}$ and $\mathrm{BC}_{\mathrm{ff}}$ was used for the source apportionment of $\mathrm{CO}$ and compared with a method based on the $\mathrm{CO} / \mathrm{NO}_{x}$ emission ratios.

\section{Material and methods}

\subsection{Sampling sites}

Simultaneous measurements of $\mathrm{eBC}$ and $\mathrm{CO}$ were performed at the National Centre of Scientific Research (NCSR) Demokritos (DEM) and at the National Observatory of Athens (NOA), from 6 December 2014 until 10 March 2015 (Fig. 1). The campus of Demokritos is situated at the foot of Mount Hymettus in Agia Paraskevi and covers an area of 600 acres in a forest of pine trees. Situated at $7 \mathrm{~km}$ northnortheast from Athens centre (Triantafyllou et al., 2016), the Global Atmosphere Watch (GAW) Demokritos measurement station $\left(37.99^{\circ} \mathrm{N}, 23.82^{\circ} \mathrm{E}, 270 \mathrm{~m}\right.$ a.s.l) is considered representative of the suburban areas of the Athens Metropolitan Area (AMA). NOA's station is located at its central premises at Thiseio, in the centre of Athens and on the top of Hill of the Nymphs $\left(38.0^{\circ} \mathrm{N}, 23.7^{\circ} \mathrm{E}, 107 \mathrm{~m}\right.$ a.s.l.). Its central setting, still relatively far (further than $500 \mathrm{~m}$ ) from main traffic lines, can be considered ideal for monitoring the air pollution urban background of Athens. 


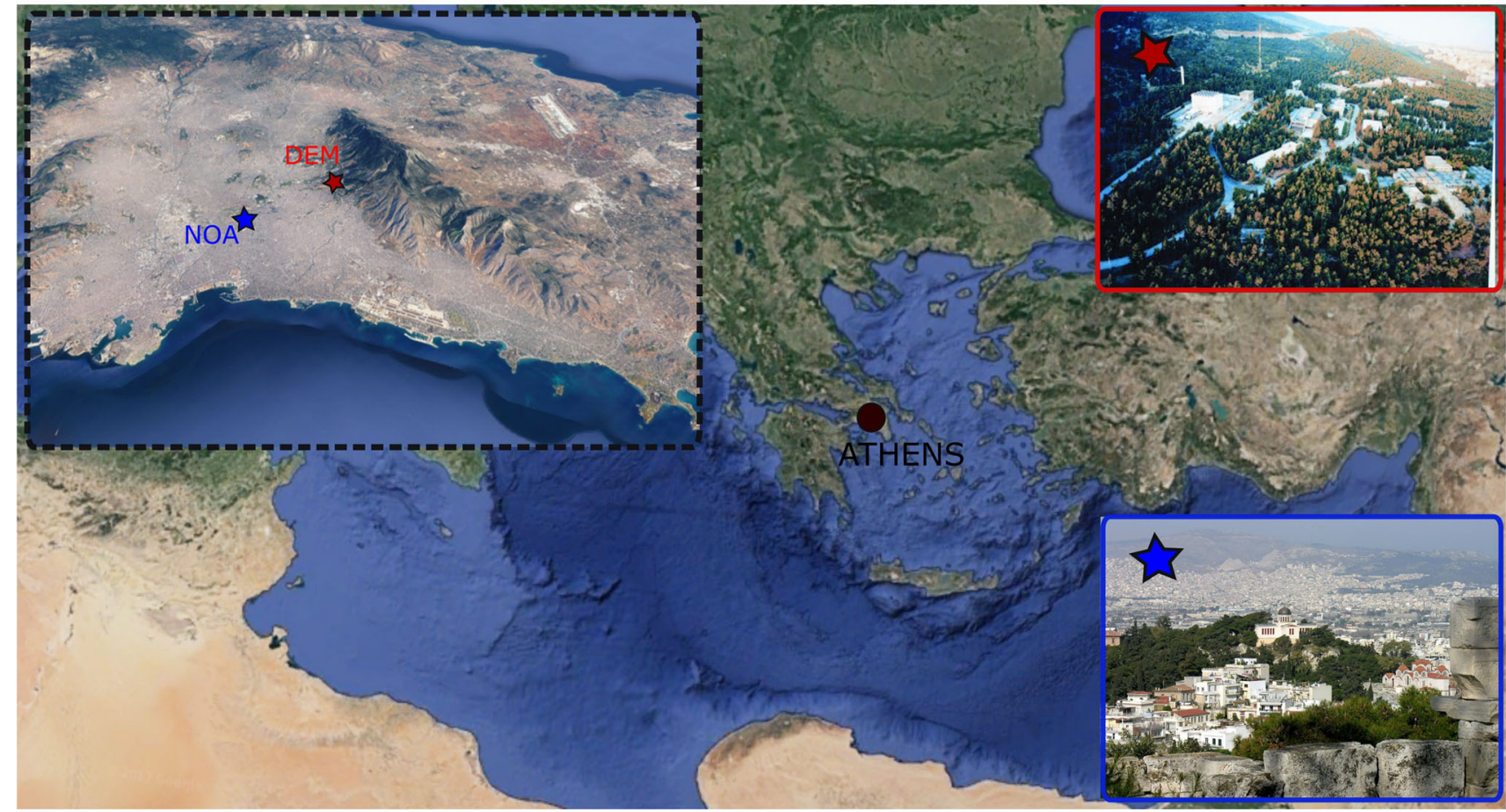

Figure 1. Regional map along with 3-D satellite map of the Athens Metropolitan area (black dashed rectangle), and photos of the NCSR Demokritos (DEM) campus in Agia Paraskevi (Athens suburban, red star), and of the National Observatory of Athens (NOA) at Thiseio (Athens centre, blue star).

\subsection{Measurements of aerosol light absorption and carbon monoxide}

\subsubsection{Aerosol light absorption and equivalent black carbon}

The aerosol light absorption coefficient, $b_{\text {abs }}$, was retrieved at each station by means of a seven-wavelength (370, 470, 520, 590, 660, 880 and $950 \mathrm{~nm}$ ) Aethalometer (Magee Scientific Corp., Berkeley, CA 94703, USA) with a 5 min temporal resolution. At DEM, the new generation AE33 Aethalometer model was used, which provides a real-time compensation for multiple scattering in the filter matrix and loading effects using the DualSpot Technology ${ }^{\circledR}$ (Drinovec et al., 2015). The AE33 sampled aerosol through a $\mathrm{PM}_{2.5}$ cut-off inlet. At NOA, a Portable Aethalometer ${ }^{\circledR}$ Model AE42 was used and aerosol sampling was performed with no size cut. As BC mainly contributes to $\mathrm{PM}_{1}$ (Laborde et al., 2013; Wang et al., 2015), differences in the eBC concentrations due to the different aerodynamic diameters of sampled aerosols are expected to be negligible. Raw absorption coefficients at a given wavelength $\lambda\left(b_{\text {aeth }, \lambda}\right)$ from the AE42 dataset were corrected from loading and scattering effects following the procedure introduced by Weingartner et al. (2003).

$$
\begin{aligned}
& b_{\mathrm{abs}, \lambda}=\frac{b_{\mathrm{ATN}, \lambda}}{C_{0} \times R(\mathrm{ATN})_{\lambda}} \\
& R(\mathrm{ATN})_{\lambda}=\left(\frac{1}{f_{\lambda}}-1\right) \times \frac{\ln \left(\mathrm{ATN}_{\lambda}\right)-\ln 10}{\ln 50-\ln 10}+1
\end{aligned}
$$

As described in Eq. (1), a $C_{0}$ constant was used to correct for multiple scattering by the filter fibers and the scattering of the aerosols embedded in the filter, whereas a $R(\mathrm{ATN})$ function enabled the loading effect to be compensated for, i.e. the linearity loss in the relationship between the transmission of light through the sample-laden filter and the amount of the light-absorbing sample on the filter (Eq. 2). The value of 3.5 was used for $C_{0}$, as recommended in Zanatta et al. (2016). The compensation parameter $f_{\lambda}$ is a parameter that mainly depends on the single scattering albedo of aerosol and is expressed as follows:

$f_{\lambda}=\alpha \cdot\left(1-\operatorname{SSA}_{\lambda}\right)+1$,

where $\mathrm{SSA}_{\lambda}$ is the aerosol single scattering albedo and $\alpha$ a constant parameter, varying in the range 0.82-0.88 for the different wavelengths $(950-370 \mathrm{~nm})$. Since no simultaneous scattering coefficient measurements were available during this campaign, $f_{\lambda}$ values $\left(f_{370}=1.319, f_{470}=\right.$ $1.288, f_{520}=1.244, \quad f_{590}=1.213, f_{660}=1.213, f_{880}=$ 1.203, $f_{950}=1.203$ ) given in Drinovec et al. (2015) for an urban site with a single scattering albedo of about 0.75 were used for loading compensation at the urban background 

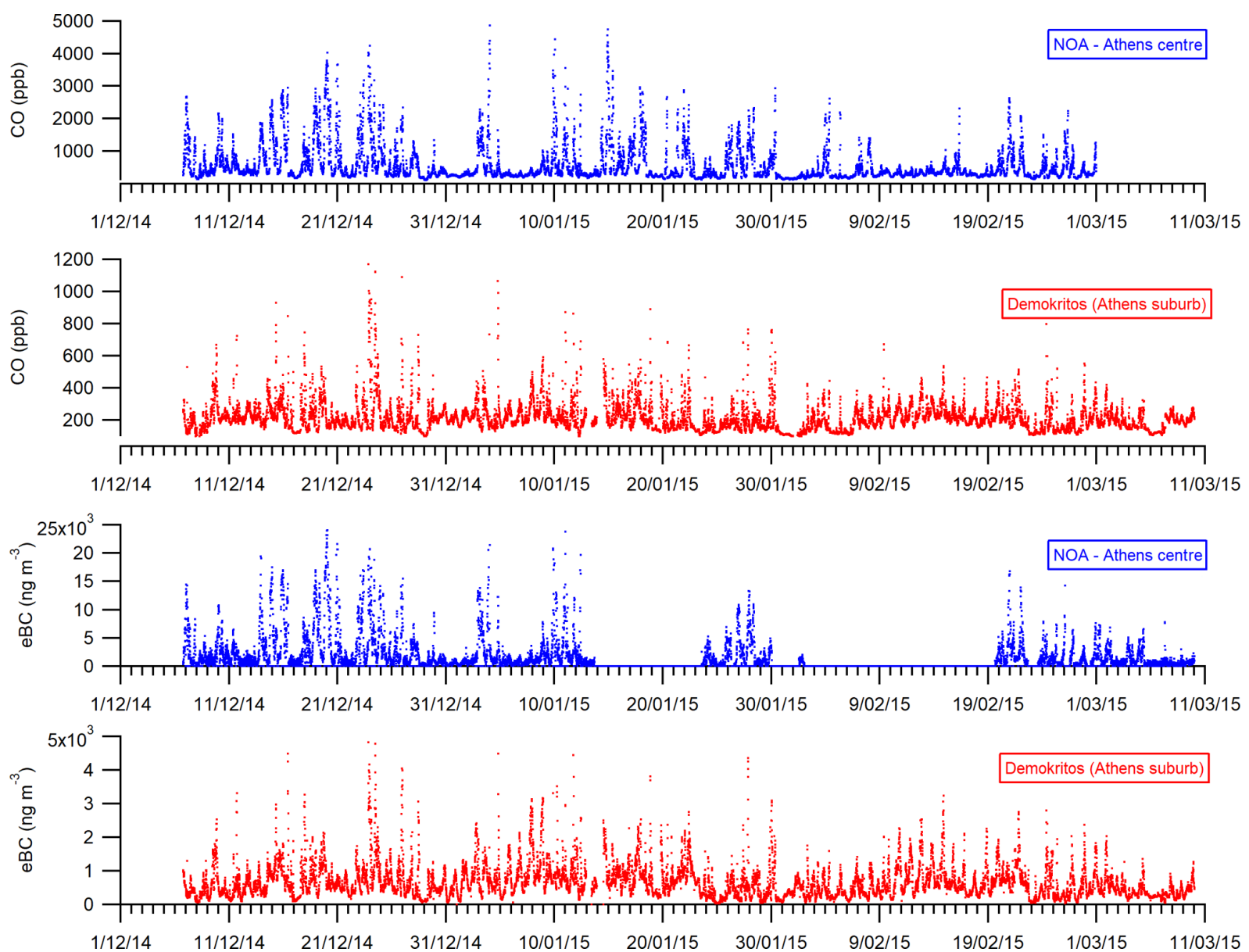

Figure 2. Time series of $10 \mathrm{~min}$ averaged $\mathrm{CO}$ and eBC concentrations measured at NOA (in blue) and DEM (red) monitoring stations from 6th December 2014 until 10th march 2015.

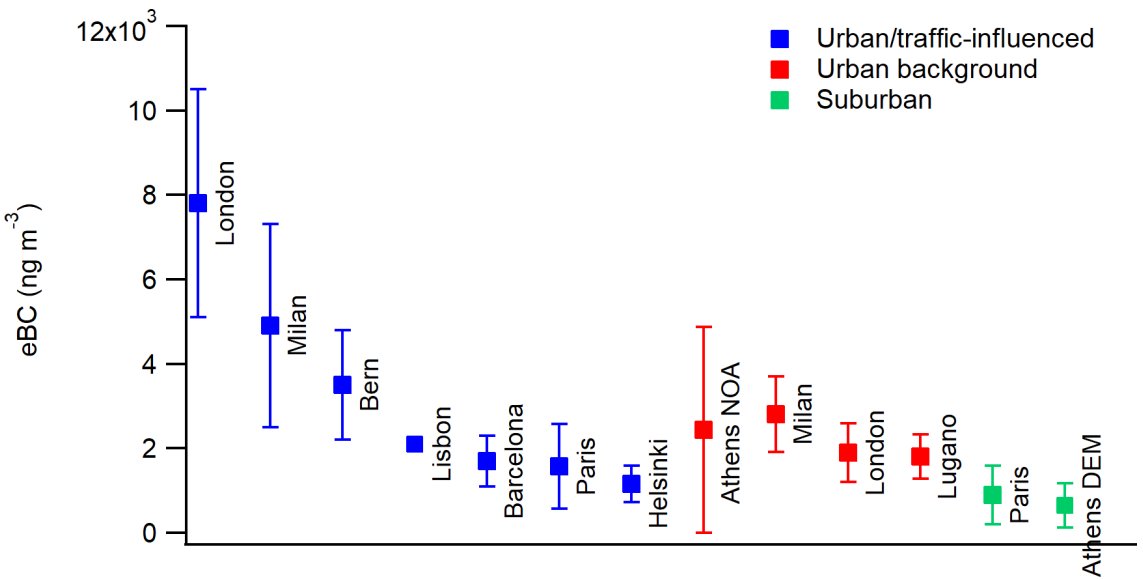

Figure 3. Levels of black carbon (mean $\pm \mathrm{SD}$ ) reported for various European cities, (blue) in traffic-influenced sites such as London (year 2009, Rechef et al., 2011), Milan (summer 2010), Lisbon (June 2000, Alves et al., 2002), Barcelona (year 2009, Reche et al., 2011), Paris (summer 2009, Zhang et al., 2013) and Helsinki (winter 2000, Hitzenberger and Tohno, 2001); (red) in urban background/residential areas such as Milan (summer 2010, Invernizzi et al., 2011), London (year 2009, Reche et al., 2011) and Lugano (year 2009, Reche et al., 2011); and (green) a suburban area of Paris (Laborde et al., 2013) along with the results from this study at NOA and DEM stations in winter 2014-2015. 
site. In order to estimate uncertainties related to the chosen $f_{\lambda}$ values, absorption coefficients calculated with $f_{\lambda}$ values taken from Drinovec et al. (2015) were compared with those using $f_{\lambda}$ values calculated for a SSA value of 0.8 . Differences in the absorption coefficients calculated using $f_{\lambda}$ values calculated for an SSA of 0.8 (e.g. $f_{6}=1.166$ ) and those found in Drinovec et al., (2015) were found to be lower than $1 \%$. The performance of the loading compensation algorithm was examined using the approach described in Drinovec et al., (2015), where the dependence of the absorption Ångström exponent $\alpha$ to the attenuation of light is analysed. The slope that derives from the regression between the Ångström exponent $\alpha$, calculated from $\alpha=\ln \left(b_{\mathrm{abs}, 470 \mathrm{~nm}} / b_{\mathrm{abs}, 880 \mathrm{~nm}} / \ln (880 / 470)\right)$ and the attenuation has been calculated. The value of the slope is equal to -0.0055 before compensation and close to $0(-0.0005)$ after compensation of the data, thus indicating that the shadowing effect was correctly accounted for.

Eventually, aerosol light absorption coefficients were converted into mass concentration of the equivalent $B C(e B C)$ as defined by Petzold et al. (2013). BC is historically defined from Aethalometer measurements at $880 \mathrm{~nm}$. At $880 \mathrm{~nm}$, no significant difference in the mass absorption cross section (MAC) at $880 \mathrm{~nm}$ between eBC originating from traffic and wood burning emission is expected (Zotter et al., 2017). The eBC mass concentration was derived in this study by multiplying the $b_{\text {abs }}$ coefficient at $880 \mathrm{~nm}$ with a constant value of MAC of $4.6 \mathrm{~m}^{2} \mathrm{~g}^{-1}$ (determined from the comparison with simultaneous measurements at DEM of elemental carbon). An extensive description of EC / OC (organic carbon) measurements at DEM is available in Diapouli et al. (2014). Assuming an absorption Angstrom exponent of 1.0, the MAC used here is 6.13 when adjusted to $637 \mathrm{~nm}$. Our MAC value is at the lower limit of the values reported by Zanatta et al. (2016), for nine rural background stations across Europe $\left(7.5-13.3 \mathrm{~m}^{2} \mathrm{~g}^{-1}\right.$, calculated for $\left.637 \mathrm{~nm}\right)$, and within the range of values reported by Hitzenberger et al. (2006) for an urban background site in Vienna (5.9-7.5 at $637 \mathrm{~nm}$ ).

\subsubsection{Carbon monoxide and nitrogen oxides}

Ambient $\mathrm{CO}$ mixing ratios were measured at DEM station at a time resolution of $1 \mathrm{~Hz}$ using a cavity ring-down spectroscopy analyser (Model G2401, Picarro, CA, USA), which provides high-resolution and low-detection-limit $\mathrm{CO}, \mathrm{CO}_{2}$ and $\mathrm{CH}_{4}$ ambient mixing ratios in line with GAW standards. Air was pulled through a $5 \mathrm{~m}$ line at about $0.4 \mathrm{~L} \mathrm{~min}^{-1}$, and water was removed from the sample using a Nafion ${ }^{\mathrm{TM}}$ copolymer membrane dryer (http://www.permapure.com/resources/ all-about-nafion-and-faq/). CO measurements were obtained with a typical precision ( 1 sigma) of about \pm 4 ppbv in a $1 \mathrm{~s}$ measurement for concentrations ranging between 75 and $300 \mathrm{ppbv}$. Additionally, hourly measurements of $\mathrm{NO}_{x}$ were available from the monitoring station of the Greek Ministry of Environment and Energy (http://www.ypeka.gr), situated $300 \mathrm{~m}$ from DEM station.

$\mathrm{CO}$ and $\mathrm{NO}_{x}$ were determined at the NOA station with a 1 min integration time using a Horiba APMA-360 series automatic gas analyser (non-dispersive infrared technique, scale: 0-20 ppmv, lower detectable limit: $0.05 \mathrm{ppmv}$ ) and a Horiba APNA-360 series (chemiluminescence technique, scale: $0-1000$ ppbv, lower detectable limit: 0.5 ppbv), respectively.

\subsection{Source apportionment of black carbon from fossil fuel and wood burning combustion}

Source apportionment of the ambient BC concentrations was based on the method developed by Sandradewi et al. (2008) and successfully applied in several studies (Favez et al., 2009; Fourtziou et al., 2017; Fuller et al., 2014; Petit et al., 2014; Sciare et al., 2011). This model relies on the first assumption that the total absorption at a wavelength $\lambda, b_{\mathrm{abs}}(\lambda)$, is a combination of absorption due to fossil fuel $\left(b_{\mathrm{abs}}(\lambda)_{\mathrm{ff}}\right)$ and wood burning $\left(b_{\mathrm{abs}}(\lambda)_{\mathrm{wb}}\right)$ aerosols.

Furthermore, it is based on the difference in the dependency of the absorption coefficient on wavelength assuming that absorption from fossil fuel and biomass burning emissions follow different spectral dependencies. The wavelength $(\lambda)$ dependent absorption of light by aerosols $\left(b_{\text {abs }}\right)$ is proportional to $\lambda^{-\alpha}$ where $\alpha$ is the absorption Ångström exponent such that

$\frac{b_{\mathrm{abs}}\left(\lambda_{1}\right)_{\mathrm{ff}}}{b_{\mathrm{abs}}\left(\lambda_{2}\right)_{\mathrm{ff}}}=\left(\frac{\lambda_{1}}{\lambda_{2}}\right)^{-\alpha_{\mathrm{ff}}}$,

and

$\frac{b_{\mathrm{abs}}\left(\lambda_{1}\right)_{\mathrm{wb}}}{b_{\mathrm{abs}}\left(\lambda_{2}\right)_{\mathrm{wb}}}=\left(\frac{\lambda_{1}}{\lambda_{2}}\right)^{-\alpha_{\mathrm{wb}}}$.

Light absorption measurements at $\lambda_{1}=470 \mathrm{~nm}$ (UV), and $\lambda_{2}=950 \mathrm{~nm}$ (IR) are used in this approach due to the fact that when compared to $\mathrm{BC}$ from fossil fuel combustion $\left(\mathrm{BC}_{\mathrm{ff}}\right)$, wood burning aerosols $\left(\mathrm{BC}_{\mathrm{wb}}\right)$ exhibit greater absorption in the near-ultraviolet range. This enhanced absorption at near-UV range for wood burning aerosols is due to the presence of absorbing organic molecules, especially polycyclic aromatic hydrocarbons and humic-like substances (Hoffer et al., 2006). Even though different pairs of near-UV and near-IR wavelengths can be used, it is recommended to use the pair $470 \mathrm{~nm}$ versus $950 \mathrm{~nm}$. The choice of 470 against 370 is even more critical, as explained in Zotter et al. (2017) since VOCs or other absorbing non-BC particles can interfere with measurements with the $370 \mathrm{~nm}$ Aethalometer channel. By solving Eqs. (4-6), unique values of $b_{\mathrm{abs}}\left(\lambda_{\mathrm{UV}}\right)_{\mathrm{wb}}$, $b_{\mathrm{abs}}\left(\lambda_{\mathrm{IR}}\right)_{\mathrm{wb}}, b_{\mathrm{abs}}\left(\lambda_{\mathrm{UV}}\right)_{\mathrm{ff}}$ and $b_{\mathrm{abs}}\left(\lambda_{\mathrm{IR}}\right)_{\mathrm{ff}}$ can be calculated, thus leading to the determination of $\mathrm{BC}_{\mathrm{wb}}$ and $\mathrm{BC}_{\mathrm{ff}}$ : 
$b_{\mathrm{abs}}\left(\lambda_{\mathrm{UV}}\right)_{\mathrm{wb}}=\frac{1}{1-\left(\frac{\lambda_{\mathrm{UV}}}{\lambda_{\mathrm{IR}}}\right)^{-\alpha_{\mathrm{ff}}} \cdot\left(\frac{\lambda_{\mathrm{UV}}}{\lambda_{\mathrm{IR}}}\right)^{\alpha_{\mathrm{wb}}}} \times$

$\left(b_{\mathrm{abs}}\left(\lambda_{\mathrm{UV}}\right)-\left(\frac{\lambda_{\mathrm{UV}}}{\lambda_{\mathrm{IR}}}\right)^{-\alpha_{\mathrm{ff}}} \cdot b_{\mathrm{abs}}\left(\lambda_{\mathrm{IR}}\right)\right)$,

$b_{\mathrm{abs}}\left(\lambda_{\mathrm{IR}}\right)_{\mathrm{wb}}=\left(\frac{\lambda_{\mathrm{UV}}}{\lambda_{\mathrm{IR}}}\right)^{\alpha_{\mathrm{wb}}} \cdot b_{\mathrm{abs}}\left(\lambda_{\mathrm{UV}}\right)_{\mathrm{wb}}$,

$b_{\mathrm{abs}}\left(\lambda_{\mathrm{UV}}\right)_{\mathrm{ff}}=b_{\mathrm{abs}}\left(\lambda_{\mathrm{UV}}\right)-b_{\mathrm{abs}}\left(\lambda_{\mathrm{UV}}\right)_{\mathrm{wb}}$,

$b_{\mathrm{abs}}\left(\lambda_{\mathrm{IR}}\right)_{\mathrm{ff}}=b_{\mathrm{abs}}\left(\lambda_{\mathrm{IR}}\right)-b_{\mathrm{abs}}\left(\lambda_{\mathrm{IR}}\right)_{\mathrm{wb}}$,

$\mathrm{BC}_{\mathrm{ff}}=\frac{b_{\mathrm{abs}}\left(\lambda_{\mathrm{IR}}\right)_{\mathrm{ff}}}{b_{\mathrm{abs}}\left(\lambda_{\mathrm{IR}}\right)} \times \mathrm{EBC}$,

$\mathrm{BC}_{\mathrm{wb}}=\mathrm{EBC}-\mathrm{BC}_{\mathrm{ff}}$.

The application of the model requires the selection of suitable Ångström exponents for fossil fuel $\left(\alpha_{\mathrm{ff}}\right)$ and wood burning $\left(\alpha_{\mathrm{wb}}\right)$, since one of the greatest uncertainties of the model is associated with the a priori assumed $\alpha$ values for both types of emissions. Reported Ångström exponents range between 0.8 and 1.1 for pure traffic. For wood burning a wider range of values has been observed (0.9-3.5), even though $\alpha_{\mathrm{wb}}$ equal to 2.0 has long been considered a typical value for wood burning aerosol (Favez et al., 2009; Fuller et al., 2014; Herich et al., 2011; Petit et al., 2014; Sciare et al., 2011). Recently, Zotter et al. (2017) recommended to use $\alpha_{\mathrm{ff}}=0.9$ and $\alpha_{\mathrm{wb}}=1.68$, obtained by fitting the model outputs (calculated with the absorption coefficients at 470 and $950 \mathrm{~nm}$ ) against the fossil fraction of EC derived from ${ }^{14} \mathrm{C}$ measurements. At DEM site, a previous study showed that values of $a_{\mathrm{wb}}$ below 1.7 were not appropriate for the specific site (Diapouli et al., $2017 b$ ). On top of that, during fire events, Ångström exponent values up to 2 have been observed at DEM. Taking into consideration these results, absorption Ångström exponents of 0.9 and 2.0 for pure traffic $\left(\alpha_{\mathrm{ff}}\right)$ and wood burning $\left(\alpha_{\mathrm{wb}}\right)$, respectively, were used in this study.

It should also be noted that coal-burning organic aerosol is known to significantly absorb light at near-UV wavelengths (Yang et al., 2009) and may thus interfere with $b_{\mathrm{abs}}\left(\lambda_{\mathrm{UV}}\right)_{\mathrm{wb}}$. Lignite coal is the single most important local energy source in Greece (Kavouridis, 2008). However, interferences from coal use are expected to be very low, as the lignite-fired power plants are located far away from Athens $(>200 \mathrm{~km}$ distance).

\subsection{Source apportionment of carbon monoxide from fossil fuel and wood burning combustion}

The partitioning of $\mathrm{CO}$ ambient concentrations into different sources has been investigated in a limited number of studies and was mainly based on the variable isotopic composition of CO (Gros et al., 2002; Kato et al., 1999; Saurer et al., 2009). In the absence of isotopic analysis, we use two different models for the source apportionment, based on the correlations between $\mathrm{CO}$ and other combustion tracers.

\subsubsection{Model 1: the CO-NO $\mathrm{C}_{x}$ linear model}

The $\mathrm{CO} / \mathrm{NO}_{x}$ ratio has been used in the past as a diagnostic to characterize different types of emission sources (Fujita et al., 1992; Ravindra et al., 2006; Saurer et al., 2009; Wahlina et al., 2001). It can serve as a useful tool for sourceapportioning $\mathrm{CO}$ concentrations at monitoring stations part of national networks where only regulated air pollutants are often measured. The $\mathrm{CO}-\mathrm{NO}_{x}$ linear model, introduced by Saurer et al. (2009), relies on the fact that both $\mathrm{CO}$ and $\mathrm{NO}_{x}$ are common products of combustion processes. Assuming that the only significant combustion processes in urban environments are traffic and wood burning for residential heating (in addition to the regional background, and a minor contribution by industrial processes), the concentrations of $\mathrm{NO}_{x}$ and $\mathrm{CO}$ can be expressed as follows:

$$
\begin{aligned}
& {\left[\mathrm{NO}_{x}\right]=\left[\mathrm{NO}_{x}\right]_{\mathrm{bgd}}+\left[\mathrm{NO}_{x}\right]_{\mathrm{ff}}+\left[\mathrm{NO}_{x}\right]_{\mathrm{wb}},} \\
& {[\mathrm{CO}]=[\mathrm{CO}]_{\mathrm{bgd}}+[\mathrm{CO}]_{\mathrm{ff}}+[\mathrm{CO}]_{\mathrm{wb}},}
\end{aligned}
$$

where $[X]_{\mathrm{ff}}$ and $[X]_{\mathrm{wb}}$ represent the concentration of the tracer $X$ resulting from fossil fuel (mainly traffic) and wood burning, respectively, whereas $[X]_{\text {bgd }}$ represent the background concentration of $X$.

The $\mathrm{CO}-\mathrm{NO}_{x}$ linear model is based on the distinct $\mathrm{CO} / \mathrm{NO}_{x}$ ratios for the two emission sources, where the wood burning emission ratio, $r_{\mathrm{wb}}$, is much larger than the one for traffic, $r_{\mathrm{ff}}$. Considering that photochemical processes do not substantially affect the ambient concentrations of $\mathrm{CO}$ and $\mathrm{NO}_{x}$ in winter, the ratios of the concentrations can be regarded as approximately the same as their respective emission ratios, $[\mathrm{CO}]_{\mathrm{ff}} /\left[\mathrm{NO}_{x}\right]_{\mathrm{ff}} \approx r_{\mathrm{ff}}$ and $[\mathrm{CO}]_{\mathrm{wb}} /\left[\mathrm{NO}_{x}\right]_{\mathrm{wb}} \approx$ $r_{\mathrm{wb}}$. Based on this assumption, we can consider that $r_{\mathrm{ff}}$ and $r_{\mathrm{wb}}$ are given, and as a consequence Eq. (1) can be rewritten as follows:

$\left[\mathrm{NO}_{x}\right]=\left[\mathrm{NO}_{x}\right]_{\mathrm{bgd}}+\frac{[\mathrm{CO}]_{\mathrm{ff}}}{r_{\mathrm{ff}}}+\frac{[\mathrm{CO}]_{\mathrm{wb}}}{r_{\mathrm{wb}}}$.

Equations (14) and (15) allow $[\mathrm{CO}]_{\mathrm{ff}}$ and $[\mathrm{CO}]_{\mathrm{wb}}$ to be determined. The concentration of $\mathrm{CO}$ originating from wood burning emissions can be expressed as follows:

$$
\begin{aligned}
& {[\mathrm{CO}]_{\mathrm{wb}}=\frac{r_{\mathrm{wb}}}{r_{\mathrm{ff}}-r_{\mathrm{wb}}} \times\left[[\mathrm{CO}]_{\mathrm{bgd}}-[\mathrm{CO}]+r_{\mathrm{ff}}\left(\left[\mathrm{NO}_{x}\right]\right.\right.} \\
& \left.\left.-\left[\mathrm{NO}_{x}\right]_{\mathrm{bgd}}\right)\right] .
\end{aligned}
$$

Defining the emission ratios $r_{\mathrm{wb}}$ and $r_{\mathrm{ff}}$ is a crucial step for the source apportionment of $\mathrm{CO}$. The methodology used for their selection is presented in Sect. 3.3.2

It is important here to mention the limitations of this model for $\mathrm{CO}$ apportionment. Firstly, it requires an a priori knowledge of the emission ratios $r_{\mathrm{ff}}$ and $r_{\mathrm{wb}}$. Secondly, it is based on the hypothesis that the $\mathrm{CO} / \mathrm{NO}_{x}$ ratio remains constant, while in fact it could be affected by photochemistry. $\mathrm{CO}$ is a long-lived species with an atmospheric lifetime of several 
days to several weeks; hence, photochemical processes influence $\mathrm{CO}$ concentrations to a limited extent. In contrast, $\mathrm{NO}_{x}$ is much more reactive species. Consequently, any change in reactive nitrogen compounds, mainly by photochemistry, would alter the $\mathrm{CO} / \mathrm{NO}_{x}$ ratio.

\subsubsection{Model 2: $\mathrm{CO}-\mathrm{BC}_{\mathrm{wb}}-\mathrm{BC}_{\mathrm{ff}}$ multiple linear regression model}

The second model for $\mathrm{CO}$ source apportionment is based on the existing relation between the concentrations of $\mathrm{CO}$ and $\mathrm{BC}$, introducing advantages in order to overcome the limitations of the previously presented $\mathrm{CO}-\mathrm{NO}_{x}$ linear model.

In a similar manner to model 1 , considering both $\mathrm{CO}$ and $\mathrm{BC}$ are exclusively produced by combustion processes and that in the urban environment, the $\mathrm{CO} / \mathrm{BC}$ ratios can be regarded as equivalent to their source emission ratio, the $\mathrm{CO}$ concentration can be expressed as follows:

$[\mathrm{CO}]=[\mathrm{CO}]_{\mathrm{bdg}}+r_{\mathrm{ff}}^{\prime} \times[\mathrm{BC}]_{\mathrm{ff}}+r^{\prime}{ }_{\mathrm{wb}} \times[\mathrm{BC}]_{\mathrm{wb}}$,

where $r_{\mathrm{ff}}^{\prime}=[\mathrm{CO}]_{\mathrm{ff}} /[\mathrm{BC}]_{\mathrm{ff}}$ and $r_{\mathrm{wb}}^{\prime}=[\mathrm{CO}]_{\mathrm{wb}} /[\mathrm{BC}]_{\mathrm{wb}}$ are the relevant emission ratios at the source. The difference of our approach in this second model resides in the way that this equation is solved. Unlike the $\mathrm{CO}-\mathrm{NO}_{x}$ linear model, here a priori knowledge of $r_{\mathrm{wb}}$ and $r_{\mathrm{ff}}$ emission ratios is not required. Instead, $\mathrm{BC}_{\mathrm{ff}}$ and $\mathrm{BC}_{\mathrm{wb}}$ are known variables (determined previously using the method presented in Sect. 2.2), and $r_{\mathrm{ff}}^{\prime}$ and $r_{\mathrm{wb}}^{\prime}$ can be calculated by a multiple linear regression model applied to Eq. (17).

Using $r_{\text {ff }}^{\prime}$ and $r_{\text {wb }}^{\prime}$ resulting from the model, the concentration of $\mathrm{CO}$ attributed to fossil fuel and wood burning sources can be estimated such that

$\mathrm{CO}_{\mathrm{ff}}=r_{\mathrm{ff}}^{\prime} \times[\mathrm{BC}]_{\mathrm{ff}}$,

and

$\mathrm{CO}_{\mathrm{wb}}=r_{\mathrm{wb}}^{\prime} \times[\mathrm{BC}]_{\mathrm{wb}}$.

Moreover, the hypothesis of negligible photochemical chemistry is met for the timescale considered in this study and for the long-lived species BC and CO and therefore should not have a significant impact on their ambient ratio.

While multiple linear regressions are known techniques for source apportionment, they have not yet been applied to investigate wood burning contribution to $\mathrm{CO}$ using the Aethalometer's model results. The considerable increase in measurements carried out using Aethalometers makes this technique an interesting and very useful methodology for apportioning $\mathrm{CO}$ concentrations.

\section{Results and discussion}

\subsection{Levels and diurnal variations of black carbon and carbon monoxide}

A statistical summary of $\mathrm{eBC}$ and $\mathrm{CO}$ levels at NOA and DEM stations, as well as their respective time series, is displayed in Table 1 and Fig. 2, respectively. Median eBC and CO levels were, respectively, 2.3 and 1.7 times higher at NOA station compared to DEM station. In particular, on days with stagnant atmospheric conditions (low wind speed), concentrations of both combustion tracers were up to 10 times higher at NOA compared to DEM. During days with more turbulence, the levels of $\mathrm{eBC}$ and $\mathrm{CO}$ were similar at both stations, as a result of intensive mixing and uniform horizontal pollutants' dispersion in the Athens valley. As shown in Fig. 3, eBC mass concentrations observed at NOA station are similar to previously reported values in various urban background sites of highly populated European cities, whereas eBC concentrations at DEM are of the same order of magnitude as in residential urban or suburban areas in Europe.

Diurnal cycles of eBC and $\mathrm{CO}$, as well as wind speed and temperature, have been calculated as $1 \mathrm{~h}$ mean values and are shown in Fig. 4. Values of eBC and CO exhibit similar diurnal variability. At both stations, maximum concentrations of $\mathrm{eBC}$ and $\mathrm{CO}$ occur during morning hours (between 08:00 and 09:00 LT) and late evening (between 20:00 and 21:00 LT), suggesting common emission sources. Based on traffic volume data (Grivas et al., 2012), a first peak in the emissions from transportation is expected around 08:00 LT when people commute to work, followed by a plateau from 08:00 18:00 LT, and a secondary peak until 21:00 LT, after which traffic decreases. Wood burning emissions from residential heating are expected to increase during the evening, when temperatures drop and people are back home. As a result, the first peak in $\mathrm{EBC}$ and $\mathrm{CO}$ concentrations occurs during morning traffic rush hour, while the surface boundary layer is still shallow. At NOA peaks are considerably more pronounced compared to DEM, suggesting that each site is under the influence of different small-scale dynamics in the Athens valley (Tombrou et al., 2007). It is also interesting to observe that the average minimum of concentrations at NOA occurs during midday due to a higher boundary layer height (BLH) and corresponding aerosol dilution during day-time, when both sampling sites are under the same well-mixed atmosphere, winds are stronger, and consequently the pollutants are more homogeneously dispersed in the metropolitan area. The second peak at NOA during night-time is the result of the nocturnal boundary layer (NBL) formation, with the site (elevation $107 \mathrm{~m}$ ) well within the nocturnal boundary layer (Kassomenos and Koletsis, 2005), leading to an accumulation of atmospheric pollutants from combustion sources active at night. During the late hours of the night, the minimum of the $24 \mathrm{~h}$ concentrations are observed at the periphery of the basin (DEM), where during stagnant conditions advec- 
Table 1. Statistical summary of eBC and CO concentrations at DEM and NOA stations for the period between 6th December 2014 and 10 th March 2015.

\begin{tabular}{lrrrrrrr}
\hline & $\begin{array}{r}\text { Arithmetic } \\
\text { mean } \pm \text { SD }\end{array}$ & $\begin{array}{r}\text { Geometric } \\
\text { mean }\end{array}$ & Median & $\begin{array}{r}\text { 90th } \\
\text { percentile }\end{array}$ & $\begin{array}{r}\text { 10th } \\
\text { percentile }\end{array}$ & $\begin{array}{r}\text { 1.25th } \\
\text { percentile** }\end{array}$ & $\begin{array}{r}\text { Number of data points } \\
(10 \text { min averaged) }\end{array}$ \\
\hline${\text { eBC }(\mathrm{DEM}) \mathrm{ng} \mathrm{m}^{-3}}$ & $656 \pm 519$ & 497 & 528 & 1265 & 179 & 71 & 13259 \\
$\mathrm{eBC}(\mathrm{NOA}) \mathrm{ng} \mathrm{m}^{-3}$ & $2655 \pm 3554$ & 1372 & 1198 & 6963 & 352 & 57 & 7474 \\
$\mathrm{CO}(\mathrm{DEM}) \mathrm{ppbv}$ & $214 \pm 95$ & 199 & 195 & 315 & 125 & 101 & 13259 \\
$\mathrm{CO}(\mathrm{NOA}) \mathrm{ppbv}$ & $555 \pm 570$ & 404 & 324 & 1282 & 196 & 143 & 12127 \\
$\mathrm{NO}_{x}(\mathrm{DEM})^{*}$ & $6.17 \pm 3.47$ & & 5.56 & 9.93 & 3.66 & 3.13 & 2238 \\
$\mathrm{NO}_{x}$ (NOA) & $29.6 \pm 42.7$ & 12.4 & 11.4 & 84.5 & 1.9 & 1.2 & 12127 \\
\hline
\end{tabular}

* $\mathrm{NO}_{x}$ measurements were available from the monitoring station of the Greek Ministry of Environment and Energy (http://www.ypeka.gr), situated 300 m from DEM station.

** Background concentration levels estimated as in Kondo et al. (2006).

tion from the urban pollution sources is reduced. Occasional downslope winds (katabatic winds) from Mount Hymettus (Amanatidis et al., 1992) may enhance air exchange from outside the NBL and at the same time induce a build up and an increase in concentrations at the Athens Basin.

\subsection{Source apportionment of $\mathrm{BC}$ and diurnal variability}

Following the deconvolution of $\mathrm{BC}$ (see Sect. 2.3), on average $\mathrm{BC}_{\mathrm{wb}}$ represents 33 and $29 \%$ of total $\mathrm{eBC}$ in $\mathrm{PM}$, at DEM and NOA, respectively. $\mathrm{BC}_{\mathrm{ff}}$ and $\mathrm{BC}_{\mathrm{wb}}$ fractions comprise the background concentration of $\mathrm{BC}\left(\mathrm{BC}_{\mathrm{bgd}}\right)$. Nevertheless, it was estimated that $\mathrm{BC}_{\mathrm{bgd}}$, defined as the 1.25 th percentile of the dataset (Kondo et al., 2006), is below $10 \%$ of the arithmetic mean concentration for both stations (Table 1). As a matter of fact, regional BC background concentrations are expected to be low compared to ambient levels in urban and suburban environments due to the low emission intensity of widespread sources.

Wood burning contribution to total $\mathrm{eBC}$ is similar to in other European cities. Indeed, a wintertime wood burning contribution of about 23-25\% has been reported for urban and suburban areas in Paris (Favez et al., 2009; Petit et al., 2014; Sciare et al., 2011), $24 \pm 11 \%$ in Zurich downtown (Herich et al., 2011), and $23 \%$ in London (Fuller et al., 2014).

Figures 5 and 6 present the diurnal cycle of $\mathrm{BC}_{\mathrm{wb}}, \mathrm{BC}_{\mathrm{ff}}$ and $\mathrm{BC}_{\text {total }}(=\mathrm{eBC})$ as well as the relative contribution of wood burning aerosols to the total $\mathrm{BC}(\mathrm{WB} \%) . \mathrm{BC}_{\mathrm{wb}}$ and WB\% show a clear diurnal trend, with values from $20-25 \%$ early in the morning to peaks of $40 \%$ during night-time, suggesting a large contribution of wood burning domestic sources spread over the region of Athens, in addition to the enhancement of concentrations at ground level because of the decrease in the boundary layer height. Other sources like industry and power generation are considered negligible as at European scales both consume less than $1 \%$ of the total amounts of wood used annually (Denier van der Gon et al., 2015). Fossil fuel sources are nevertheless the main contribu- tor to black carbon concentrations in both areas. In particular, during morning rush hours, it represents up to 70 and $90 \%$ of total $\mathrm{eBC}$ at DEM and NOA, respectively.

\subsection{Source identification of CO}

\subsubsection{Using $\mathrm{BC}_{\mathrm{wb}}$ and $\mathrm{BC}_{\mathrm{ff}}$ as tracers of fossil fuel and wood burning sources}

The association between $\mathrm{CO}$ concentration, $\mathrm{BC}_{\mathrm{wb}}$ and $\mathrm{BC}_{\mathrm{ff}}$ was examined using multiple linear regressions. Regression analysis between $\mathrm{CO}, \mathrm{BC}_{\mathrm{wb}}$ and $\mathrm{BC}_{\mathrm{ff}}$ are shown for both sites in Fig. 7. Regressions were carried out using $10 \mathrm{~min}$ averaged data which represented a sample size of 13259 and 7474 values for DEM and NOA, respectively. The best-fitted linear equation to observed data and the partial regression coefficients of the model $r_{0}^{\prime}, r_{\mathrm{ff}}^{\prime}$ and $r_{\mathrm{wb}}^{\prime}$ were calculated so that

$$
[\mathrm{CO}]=r^{\prime}{ }_{0}+r_{\mathrm{ff}}^{\prime} \times[\mathrm{BC}]_{\mathrm{ff}}+r^{\prime}{ }_{\mathrm{wb}} \times[\mathrm{BC}]_{\mathrm{wb}} .
$$

The model was run with no constraint for DEM, and the determined regression coefficients $\left(r_{\mathrm{ff}}^{\prime}\right.$ and $r_{\mathrm{wb}}^{\prime}$ for DEM) were found with a precision (standard error of regression) below $2 \%$. However, for NOA, a constraint was applied in order to achieve a mathematically and physically meaningful solution. This choice was made because of the simultaneous advection of aerosols, resulting in a significant correlation between $\mathrm{BC}_{\mathrm{wb}}$ and $\mathrm{B}_{\mathrm{ff}}$ (Fig. 7), thus making more difficult the separation of different sources based on their variability. Since the variability of the emission ratios is greater for wood burning emissions (the emission ratio strongly depends on type of biofuel and appliances used), the choice was made to constrain the emission ratio of fossil fuel $r_{\mathrm{ff}}^{\prime}$. The $r_{\mathrm{ff}}^{\prime}$ value for NOA was set identical to the one predicted by the model for DEM (i.e. equal to $0.184 \mathrm{ppbv} \mathrm{ng}^{-1} \mathrm{~m}^{3}$, see Eq. 21). This is an approximation based on the assumption that $\mathrm{BC}$ and $\mathrm{CO}$ are chemically inert and their emission ratio $r_{\mathrm{ff}}^{\prime}$ cannot differ significantly within the same urban area due to a uniform vehicle fleet mix (vehicle size class and age of vehicle fleet, environmental performance, driving behaviour, etc.). It 
(a) 5000 NOA - Athens centre

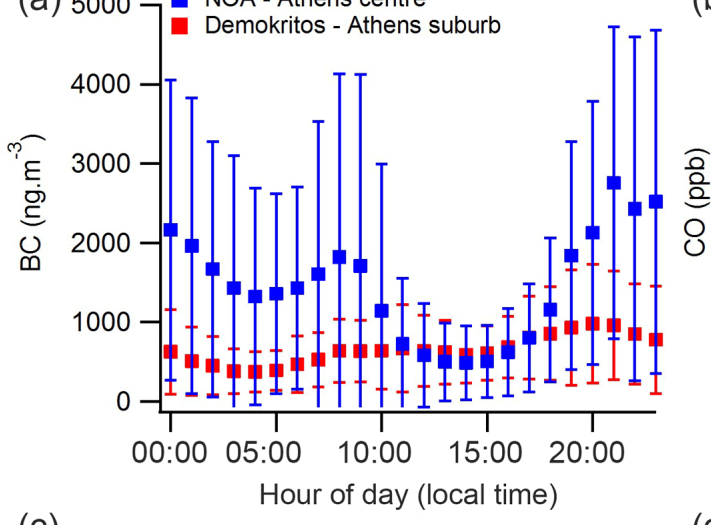

(c)

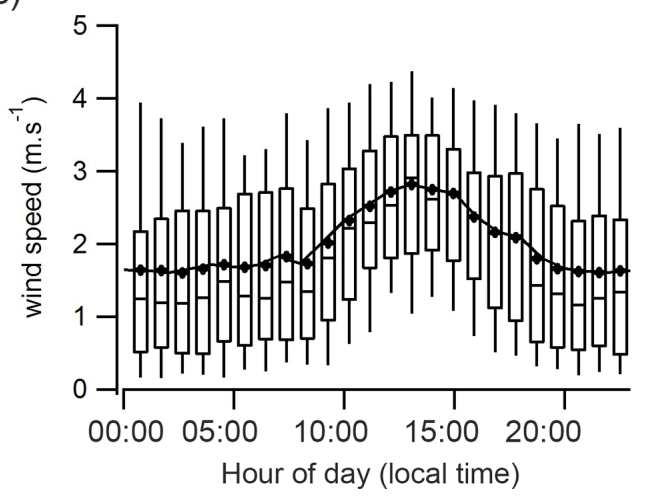

(b) 2000

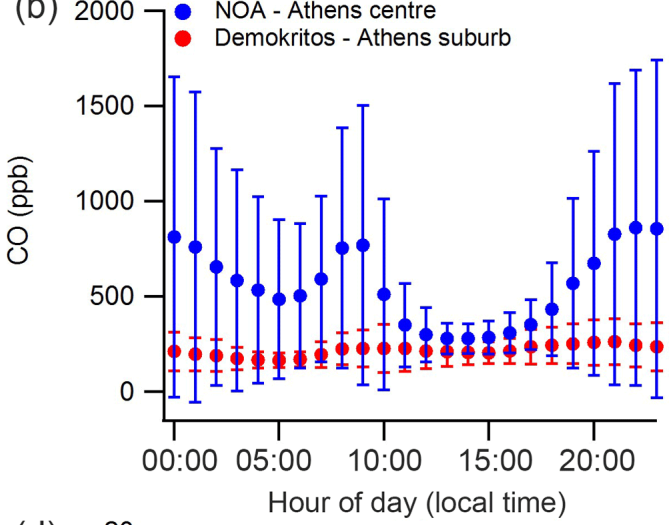

(d)

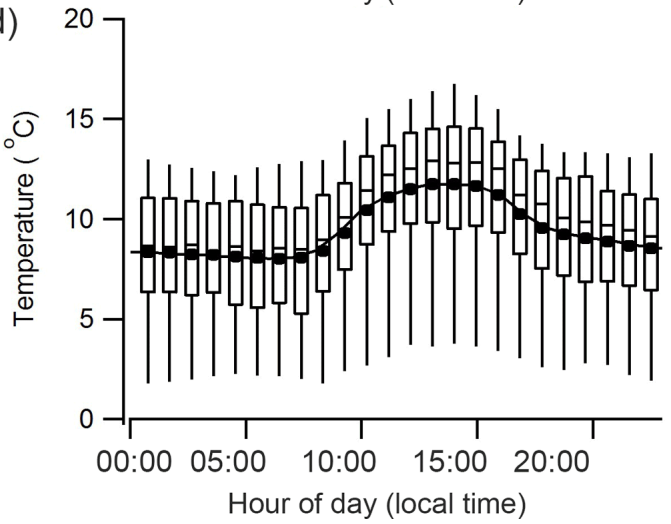

Figure 4. (a, b) Diurnal trends of BC (a) and CO (b) concentrations at NOA (blue) and DEM (red) monitoring stations (local time = UTC). Vertical bars show standard deviation to the mean value. Diurnal trends of wind speed (c) and temperature (d) measured at the meteorological station of Demokritos. Data are presented as box and whisker plots, where boxes encompass values between the 25 th and 75 th percentiles, horizontal lines represent median values, and "whiskers" give the $80 \%$ range of the values, whereas markers represent the mean values.

Table 2. $\mathrm{BC} / \mathrm{CO}\left(\mathrm{ngC} \mathrm{m}^{-3} \mathrm{ppbv}^{-1}\right)$ ratios derived from emission factors found in the literature and from ambient measurements in Athens using the multiple regression model.

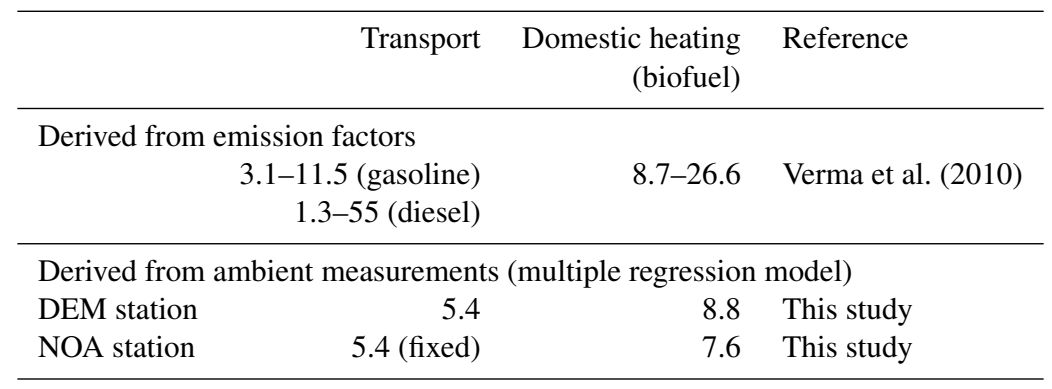

should be noted here that this assumption might introduce some uncertainty to the results. A sensitivity analysis for the NOA emission ratios was made, based on the statistical error of determined $r_{\mathrm{ff}}^{\prime}$ at DEM, equal to 1 standard deviation in the regression analysis according to Eq. (20). Hence, $r_{w b}^{\prime}$ for NOA was re-calculated using not only a single constraint value, but a range of values from the lowest (0.184-0.00137) to the highest $(0.184+0.00137)$ around the determined $r_{\mathrm{ff}}^{\prime}$ value from the multilinear regression analysis at DEM. An uncertainty of $25 \%$ was finally estimated from this exercise for the calculated $r_{\mathrm{wb}}^{\prime}$ value at NOA. The results of the multiple regression analysis applied at the two sites are presented in Fig. 8. 
Table 3. Statistical summary of calculated $\mathrm{CO}_{\mathrm{wb}}$ and $\mathrm{CO}_{\mathrm{ff}}$ concentrations, as well as $\mathrm{CO}_{\mathrm{wb}}(\%)$, using the multiple regression model (model 1) at DEM and NOA stations.

\begin{tabular}{lrrr|rrr}
\hline & \multicolumn{3}{c|}{$\mathrm{DEM}$} & \multicolumn{3}{c}{$\mathrm{NOA}$} \\
\cline { 2 - 7 } & $\mathrm{CO}_{\mathrm{wb}}(\mathrm{ppbv})$ & $\mathrm{CO}_{\mathrm{ff}}(\mathrm{ppbv})$ & $\mathrm{CO}_{\mathrm{wb}}(\%)$ & $\mathrm{CO}_{\mathrm{wb}}(\mathrm{ppbv})$ & $\mathrm{CO}_{\mathrm{ff}}(\mathrm{ppbv})$ & $\mathrm{CO}_{\mathrm{wb}}(\%)$ \\
\hline Mean $( \pm \mathrm{SD})$ & $25.1(25.7)$ & $80.2(65.5)$ & $11(9)$ & $134.5(230.6)$ & $297.3(366.9)$ & $16.3(14.3)$ \\
90th percentile & 51.9 & 156.7 & 21 & 405.9 & 731.0 & 37.1 \\
10th percentile & 4.6 & 19.8 & 3.0 & 1.9 & 50.8 & 1.0 \\
\hline
\end{tabular}

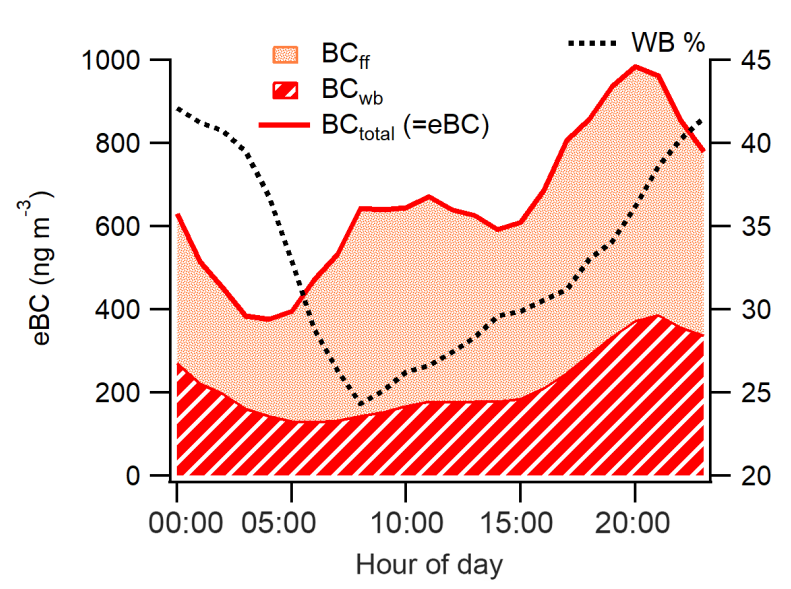

Figure 5. Diurnal cycle of $\mathrm{BC}_{\mathrm{wb}}, \mathrm{BC}_{\mathrm{ff}}, \mathrm{BC}_{\text {total }}$ and wood burning contribution to total $\mathrm{BC}\left(\mathrm{WB}\right.$, defined as $\left.\mathrm{BC}_{\mathrm{wb}} / \mathrm{BC}_{\text {total }} \cdot 100\right)$ at DEM station.

$$
\begin{gathered}
\mathrm{CO}_{\mathrm{ff}-\mathrm{DEM}}(\mathrm{ppbv})=(0.184 \pm 0.00137) \times \mathrm{BC}_{\mathrm{ff}-\mathrm{DEM}}\left(\mathrm{ng} \mathrm{m}^{-3}\right) \\
\rightarrow(\mathrm{BC} / \mathrm{CO})_{\mathrm{ff}-\mathrm{DEM}}=5.4 \mathrm{ng} \mathrm{m}^{-3} / \mathrm{ppbv} \\
\mathrm{CO}_{\mathrm{wb}-\mathrm{DEM}}(\mathrm{ppb})=(0.114 \pm 0.00216) \times \mathrm{BC}_{\mathrm{wb}-\mathrm{DEM}}\left(\mathrm{ng} \mathrm{m}^{-3}\right) \\
\rightarrow(\mathrm{BC} / \mathrm{CO})_{\mathrm{wb}-\mathrm{DEM}}=8.8 \mathrm{ng} \mathrm{m}^{-3} \mathrm{ppbv}^{-1} \\
\mathrm{CO}_{\mathrm{wb}-\mathrm{NOA}}(\mathrm{ppb})=(0.131 \pm 0.03275) \times \mathrm{BC}_{\mathrm{wb}-\mathrm{NOA}}\left(\mathrm{ng} \mathrm{m}^{-3}\right) \\
\rightarrow(\mathrm{BC} / \mathrm{CO})_{\mathrm{wb}-\mathrm{NOA}}=7.6 \mathrm{ng} \mathrm{m}^{-3} \mathrm{ppbv}^{-1}
\end{gathered}
$$

The resulting regression coefficients were applied to estimate the fraction of $\mathrm{CO}$ attributed to fossil fuel and biomass burning combustion sources, whereas the intercept values $(108.5 \pm 0.64$ and $146.8 \pm 2.5 \mathrm{ppbv}$ and for DEM and NOA, respectively) were regarded as the background concentrations of $\mathrm{CO}$. The resulting background concentrations are in very good agreement with those calculated as 1.25 th percentile of the dataset (see Table 1). It is noteworthy to mention here that $\mathrm{CO}$ background levels are very significant with regard to the ambient concentrations, representing about 26 and $46 \%$ of the arithmetic mean concentration at NOA and DEM respectively. As a matter of fact, widespread natural sources of $\mathrm{CO}$, such as plants, oceans and oxidation of hydrocarbons, in combination with its long atmospheric lifetime, are known to maintain a significant background concentration even outside urban areas. These results show that

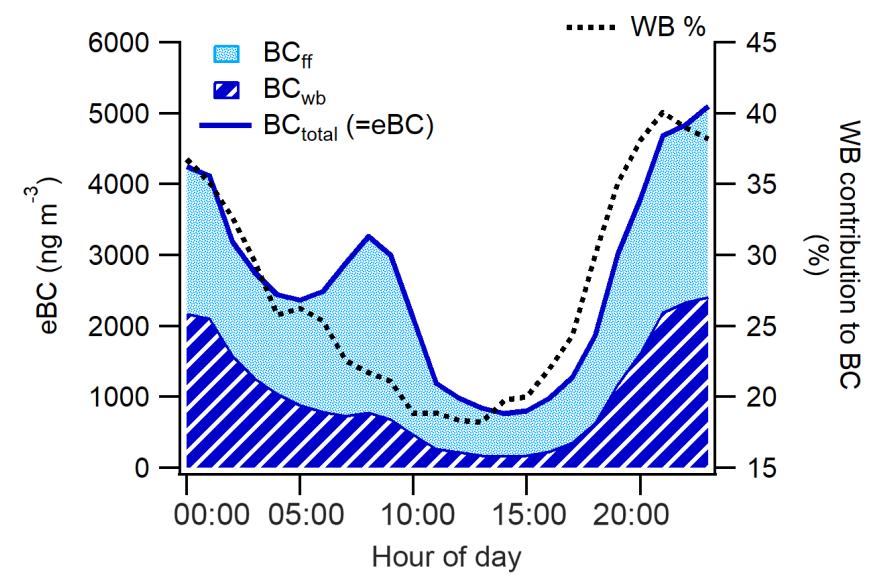

Figure 6. Diurnal cycle of $\mathrm{BC}_{\mathrm{wb}}, \mathrm{BC}_{\mathrm{ff}}, \mathrm{BC}_{\text {total }}$ and wood burning contribution to total $\mathrm{BC}\left(\mathrm{WB}\right.$, defined as $\left.\mathrm{C}_{\mathrm{wb}} / \mathrm{BC}_{\text {total }} \cdot 100\right)$ at NOA station.

the $\mathrm{BC} / \mathrm{CO}$ ratio is higher for emissions related to biomass burning compared to fossil fuel combustion, which is consistent with literature values (Pan et al., 2012). The determined values for DEM and NOA for wood burning are very similar, with a $(\mathrm{BC} / \mathrm{CO})_{\mathrm{wb}}$ ratio of $7.6-8.8 \mathrm{ng} \mathrm{m}^{-3} \mathrm{ppbv}^{-1}$. These values are also in the low range of emission ratios found in the literature for both transport and domestic heating (using biofuel) sources (see Table 2).

The time series of the deconvolution of $\mathrm{CO}$ into three fractions, namely $\mathrm{CO}_{\mathrm{ff}}, \mathrm{CO}_{\mathrm{wb}}$ and $\mathrm{CO}_{\text {background }}$, are shown in Fig. 9. According to our results, the wood burning fraction of $\mathrm{CO}$, represents on average 11 and $16 \%$ of total $\mathrm{CO}$ for DEM and NOA, respectively. In terms of concentrations, $\mathrm{CO}_{\mathrm{wb}}$ ranges between 5 and $52 \mathrm{ppbv}(\approx 25 \mathrm{ppbv}$ on average $)$ at DEM and between 2 and $406 \mathrm{ppbv}(\approx 135 \mathrm{ppbv}$ on average) at NOA (Table 3). During night-time (20:00-02:00 LT), this contribution is estimated at 15 and $25 \%$ respectively.

Diurnal variabilities of $\mathrm{CO}_{\mathrm{ff}}$ and $\mathrm{CO}_{\mathrm{wb}}$ at each site are presented in Fig. 10 (NB: different vertical scales are used for each station). As expected, $\mathrm{CO}_{\mathrm{ff}}$ presents similar variability with that of $\mathrm{BC}_{\mathrm{ff}}$, i.e. a pronounced bimodal distribution, with higher concentrations during rush hours. Along the same line, the diurnal variability of $\mathrm{CO}_{\mathrm{wb}}$ shows a unimodal pattern with increasing concentrations after 18:00 LT, due to the combination of enhanced wood burning emission, which 
Table 4. Sensitivity test of the $\mathrm{CO}-\mathrm{NO}_{x}$ linear model for a constant emission ratio for traffic $\left(r_{\mathrm{t}}\right)$ and a variable emission ratio for wood burning and comparison of model 1 (linear) versus model 2 (multilinear).

\begin{tabular}{lrrrr}
\hline & $\begin{array}{r}r_{\mathrm{t}} \\
\left(\mathrm{ppbvppv}^{-1}\right)\end{array}$ & $\begin{array}{r}r_{\mathrm{wb}} \\
\left(\mathrm{ppbv} \mathrm{ppbv}^{-1}\right)\end{array}$ & $\begin{array}{r}\text { Mean } \mathrm{CO}_{\mathrm{wb}} / \\
\text { Mean } \mathrm{CO}(\%)\end{array}$ & $\begin{array}{r}\text { Slope of regression } \\
\text { between }\left(\mathrm{CO}_{\mathrm{wb}}\right)_{\text {model1 }} \\
\text { and }\left(\mathrm{CO}_{\mathrm{wb}}\right)_{\text {model } 2}\end{array}$ \\
\hline DEM station & 7 & & & \\
\hline Test 1 & 50 & $29 \%$ & $2.4\left(R^{2}=0.52\right)$ \\
Test 2 & 7 & 100 & $28 \%$ & $2.2\left(R^{2}=0.52\right)$ \\
Test 3 & 7 & $26 \%$ & $2.1\left(R^{2}=0.52\right)$ \\
\hline NOA station & & & & \\
\hline Test 1 & 7 & 50 & $34 \%$ & $1.6\left(R^{2}=0.85\right)$ \\
Test 2 & 7 & 100 & $31 \%$ & $1.51\left(R^{2}=0.85\right)$ \\
Test 3 & 7 & 150 & $30 \%$ & $1.48\left(R^{2}=0.85\right)$ \\
\hline
\end{tabular}
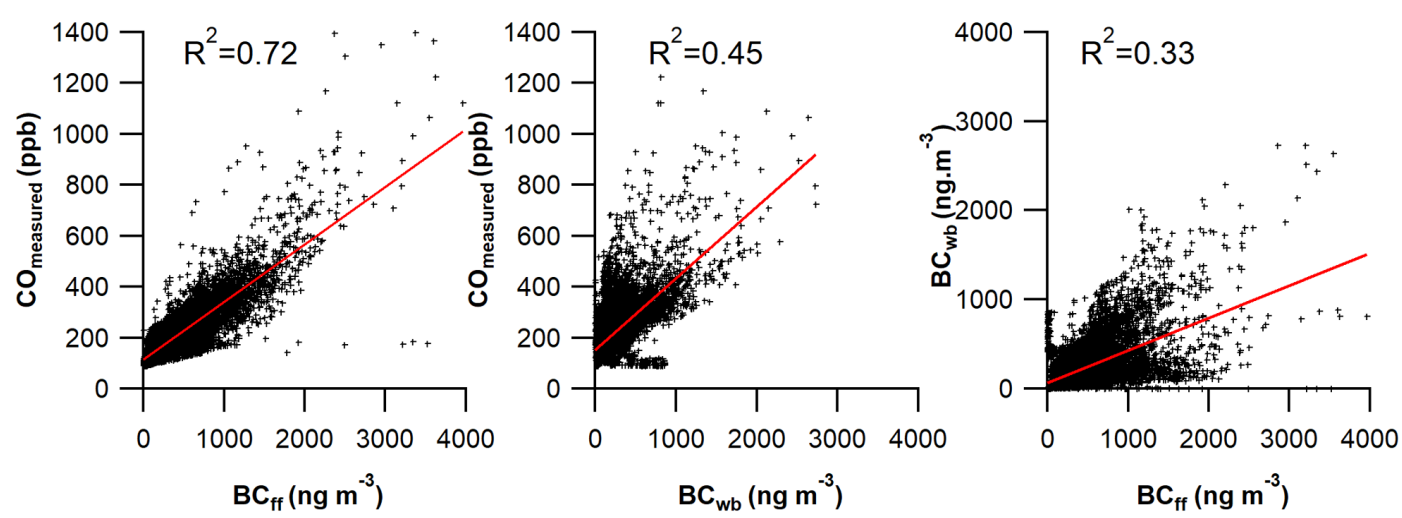

(a)
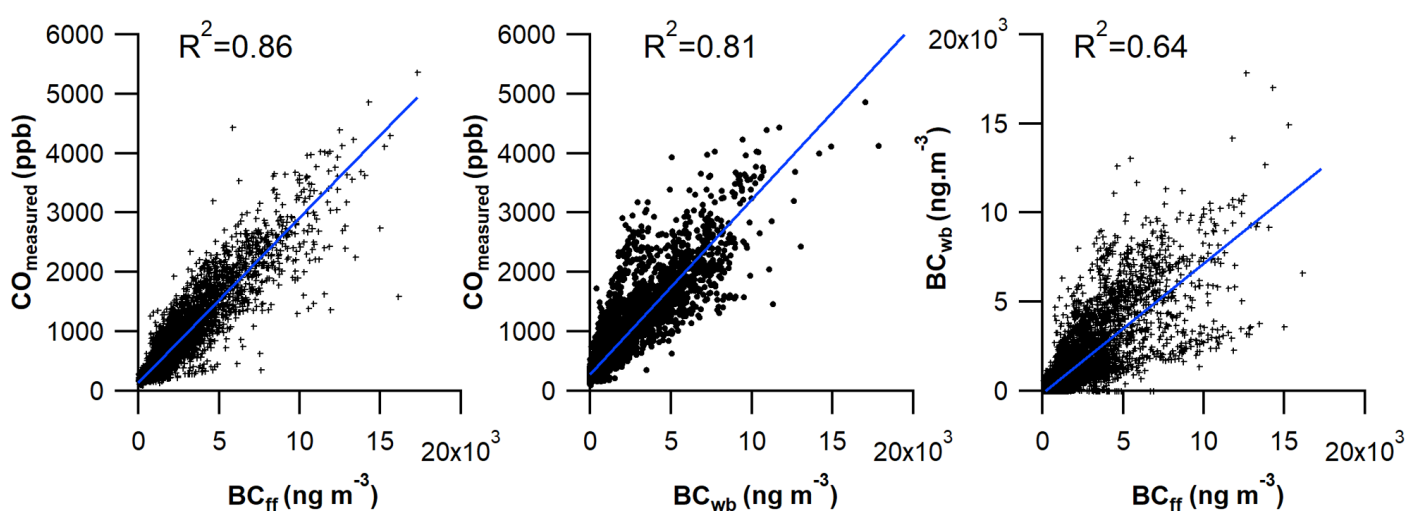

(b)

Figure 7. Correlation plots between (left) $\mathrm{CO}$ and $\mathrm{BC}_{\mathrm{ff}}$, (middle) $\mathrm{CO}$ and $\mathrm{BC}_{\mathrm{wb}}$ and (right) $\mathrm{BC}_{\mathrm{wb}}$ and $\mathrm{BC}_{\mathrm{ff}}$ for $\mathrm{DEM}(\mathbf{a})$ and $\mathrm{NOA}(\mathbf{b})$ stations.

is a source more active during evening hours, and lower ambient temperature and BLH, as discussed previously.

Comparison with other European cities is limited by the very few number of studies investigating the carbon monoxide concentration sources. Saurer et al. (2009) used the stable isotope composition of $\mathrm{CO}\left(\delta^{13} \mathrm{C}\right.$ and $\left.\delta^{18} \mathrm{O}\right)$ for the characterization of different $\mathrm{CO}$ sources at three sites in Switzer- land during winter (along with other indicators for traffic and wood combustion such as $\mathrm{NO}_{x}$ concentration and aerosol light absorption at different wavelengths) and estimated the wood burning contribution to night-time $\mathrm{CO}$ concentrations to be 70,49 and $29 \%$ for a village site dominated by domestic heating, a site close to a motorway and a rural site, respectively. These differences reflect the spatial variability 

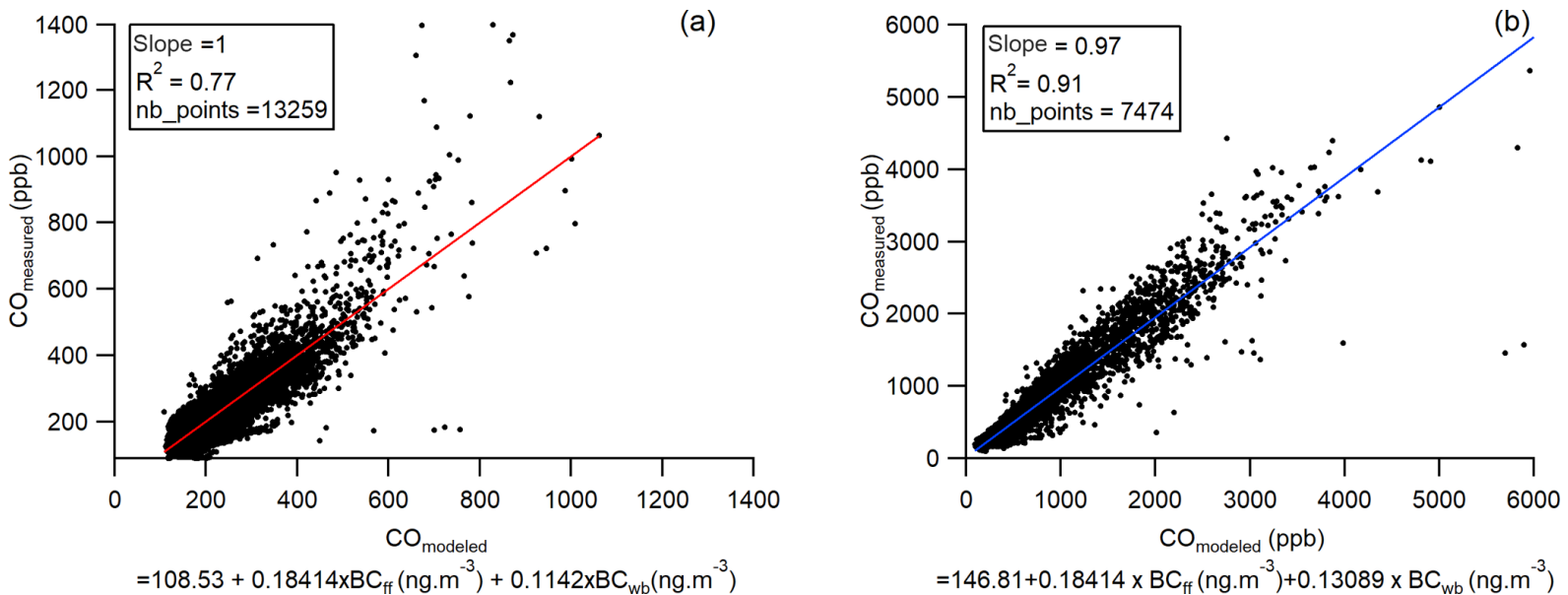

Figure 8. Best-fit linear correlations between $\mathrm{CO}$ and a combination of $\mathrm{BC}_{\mathrm{ff}}$ and $\mathrm{BC}_{\mathrm{wb}}$ for $\mathrm{DEM}(\mathbf{a})$ and NOA station (b).
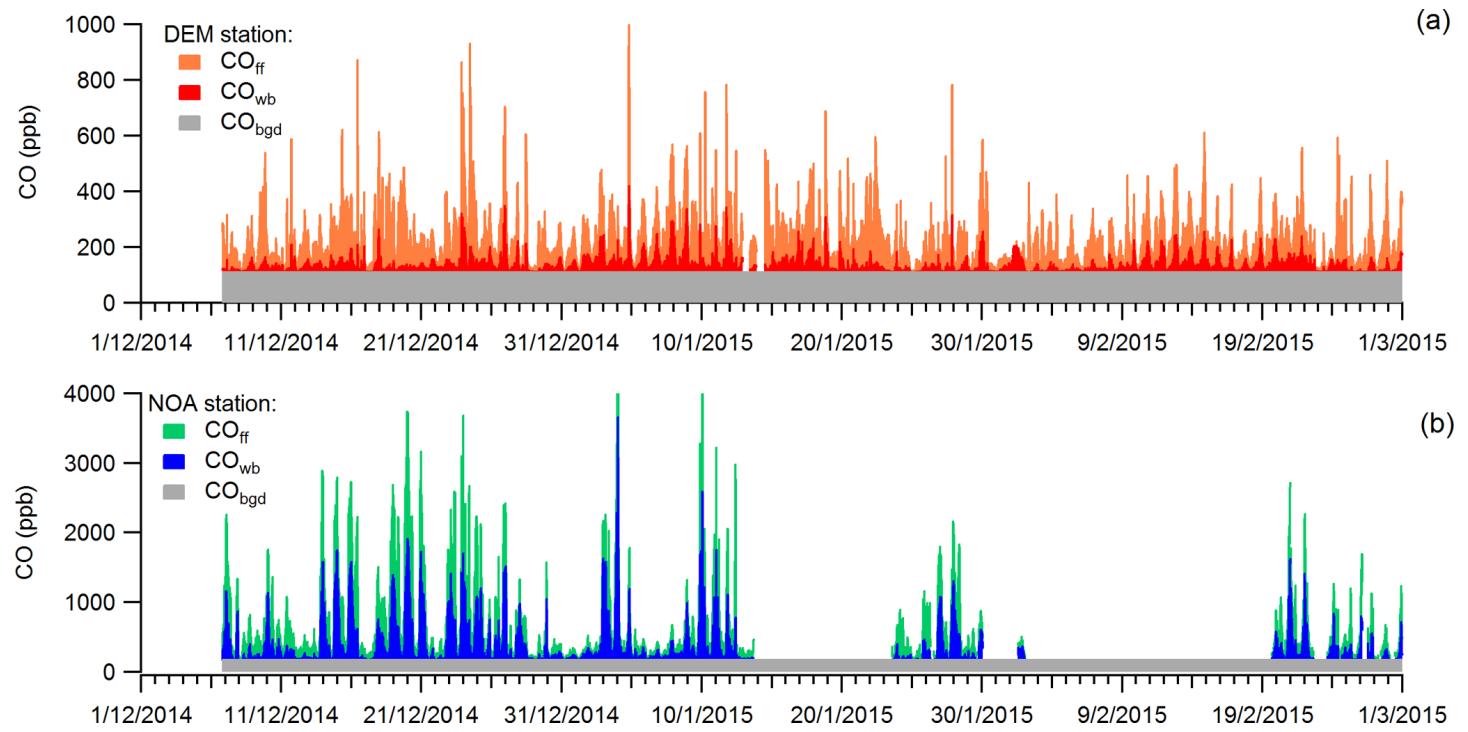

Figure 9. Time series of the calculated $\mathrm{CO}_{\mathrm{ff}}, \mathrm{CO}_{\mathrm{wb}}$ and $\mathrm{CO}_{\mathrm{bgd}}$ concentration at (a) DEM and (b) NOA stations.

in the wood burning use within the same region depending on the type of site, as well as between countries depending on the regional heating practices.

\subsubsection{Comparison of the $\mathrm{CO}-\mathrm{BC}_{\mathrm{wb}}-\mathrm{BC}_{\mathrm{ff}}$ linear model vs. the $\mathrm{CO}-\mathrm{NO}_{\mathrm{x}}$ linear model}

The results of the multiple-regression model were compared with those from the $\mathrm{CO}-\mathrm{NO}_{x}$ linear model. As presented in Sect. 2, an a priori knowledge of the emission ratio of $\mathrm{CO} / \mathrm{NO}_{x}$ from traffic $\left(r_{\mathrm{ff}}\right)$ and wood burning $\left(r_{\mathrm{wb}}\right)$ emissions is required for the $\mathrm{CO}-\mathrm{NO}_{x}$ model and therefore the choice of their value is of major importance.

In Fig. 11, the scatter plot of $\mathrm{CO}$ versus $\mathrm{NO}_{x}$ is shown for the data recorded at DEM and NOA. The dataset is mostly comprised of two well-defined slopes and the range of values of $\mathrm{CO} / \mathrm{NO}_{x}$ observed in actual air samples is 7$25 \mathrm{ppbv} \mathrm{ppbv}^{-1}$ (after subtraction of the $\mathrm{CO}_{\mathrm{bgd}}$ concentration) for DEM and NOA stations and depends on the contribution of each of the sources. As applied in other studies for similar purposes (Rodríguez and Cuevas, 2007; Saurer et al., 2009), these slopes were estimated using two best-fit lines, the first to the points aligned in the lower edge of $\mathrm{CO}$ versus $\mathrm{NO}_{x}$ scatter charts, and the second one to the points aligned in the upper edge. More precisely, they have been calculated by fitting only data below the 10th percentile and above the 90th percentile of $\mathrm{CO} / \mathrm{NO}_{x}$ data. Knowing that the lowest ratios are obtained when traffic emissions dominate (and when the contribution of wood burning is insignificant), an $r_{\mathrm{ff}}$ value of $7 \mathrm{ppbv} \mathrm{ppbv}^{-1}$ was estimated. Higher ratios were typically obtained late in the night-time, when traffic emission decreased and domestic heating increased. However, as 
(a)

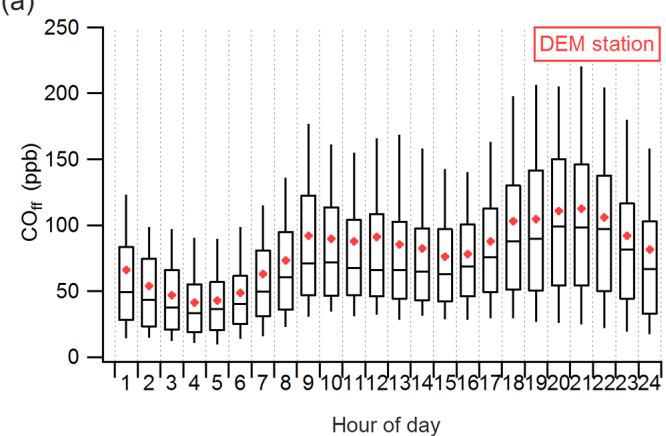

(c)

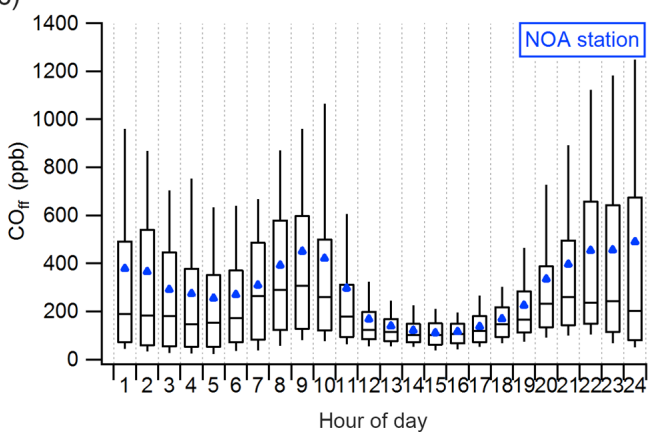

(b)

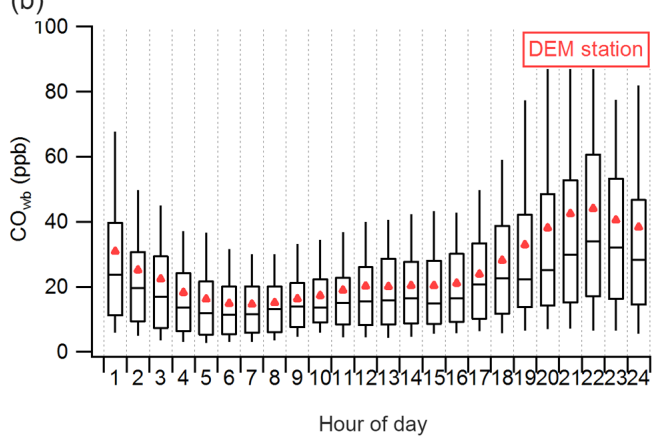

(d)

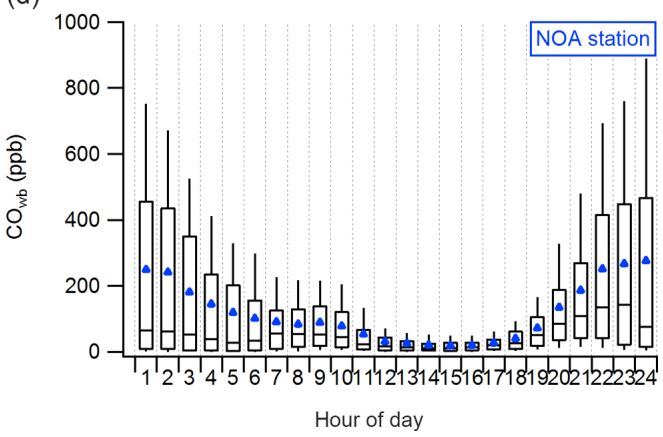

Figure 10. Diurnal variations of $\mathrm{CO}_{\mathrm{ff}}(\mathbf{a}, \mathbf{c})$ and $\mathrm{CO}_{\mathrm{wb}}(\mathbf{b}, \mathbf{d})$ at DEM $(\mathbf{a}, \mathbf{b})$ and NOA $(\mathbf{c}, \mathbf{d})$ stations. Data are presented as box and whisker plots, where boxes encompass values between the 25 th and 75 th percentiles, horizontal lines represent median values, and "whiskers" give the $80 \%$ range of the values, whereas coloured markers represent the mean values.

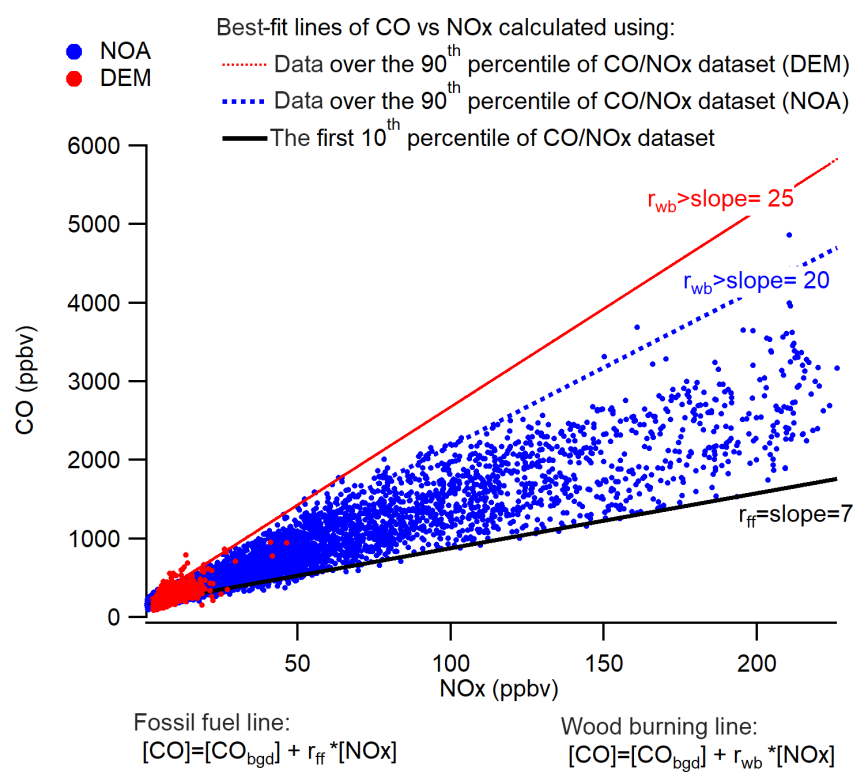

Figure 11. Scatter plot for $\mathrm{CO}$ and $\mathrm{NO}_{x}$ data from $\mathrm{NOA}$ (blue) and DEM (red) along with best-fit lines, aligned in the lower edge of $\mathrm{CO}$ versus $\mathrm{NO}_{x}$ scatter charts (black), and in the upper edge (blue and red for NOA and DEM, respectively). we do not expect a contribution of domestic heating close to $100 \%$ at any time of the day in Athens, it is impossible to estimate with accuracy the $r_{\mathrm{wb}}$ ratio based solely on this data. Nevertheless, based on "wood burning" lines from Fig. 11, and assuming that emission ratios from wood burning are similar between NOA and DEM, we estimate a $r_{\mathrm{wb}}$ ratio for the area of Athens, larger than $25 \mathrm{ppbv} \mathrm{ppbv}^{-1}$.

A sensitivity analysis of the $\mathrm{CO}-\mathrm{NO}_{x}$ model was performed using the experimentally determined $r_{\mathrm{ff}}$ (at $7 \mathrm{ppbv} \mathrm{ppbv}^{-1}$ ) and by varying $r_{\mathrm{wb}}$. Measurements performed directly at the emission source and close to the chimney exhausts during controlled wood burning experiments indicated ratios in the range of 50-150 $\mathrm{ppbv} \mathrm{ppbv}^{-1}$ (Albinet et al., 2015; Nalin, 2014). As a result, the choice was made to vary the $r_{\mathrm{wb}}$ parameter from 50 to $150 \mathrm{ppbv}_{\mathrm{ppbv}}{ }^{-1}$. The results of the analysis are presented in Table 4 . The influence of increasing $r_{\mathrm{wb}}$ at a constant $r_{\mathrm{ff}}$ resulted in a relatively minor reduction in the calculated contribution from wood burning of $2-3 \%$. A good correlation was found between both models, with coefficients of determination $R^{2}$ of 0.52 and 0.85 at DEM and NOA, respectively. The wood burning contribution to $\mathrm{CO}$ estimated using the $\mathrm{CO}-\mathrm{NO}_{x}$ linear model is higher compared to the estimations from $\mathrm{CO}-\mathrm{BC}_{\mathrm{ff}}-\mathrm{BC}_{\mathrm{wb}}$ model, by a factor of about 1.5 for NOA, which can be considered "acceptable" given the uncertainties associated with both models. A higher overestimation compared to model 2 by a factor of about 2.4 is found at DEM suburban station, 
which could be explained by the fact that the site is characterized by more aged air masses compared to the urban background NOA station. Consequently, ambient $\mathrm{CO} / \mathrm{NO}_{x}$ ratios might differ more significantly from emission ratios at DEM suburban station. These results suggest that the CO$\mathrm{NO}_{x}$ linear model probably overestimates the wood burning contribution to $\mathrm{CO}$, especially in environments characterized by aged air masses where photochemical loss of $\mathrm{NO}_{x}$ cannot be considered negligible.

\section{Conclusion}

In this study we performed a comprehensive field campaign at two surface stations in a suburban and a central area of Athens during winter 2014-2015 in order to investigate the impact of fossil fuel and biomass combustion on the urban air quality. We report measurements of particulate black carbon and $\mathrm{CO}$ and $\mathrm{NO}_{x}$ gaseous components performed simultaneously at the monitoring station of Demokritos (DEM), representative of suburban areas of the Athens Metropolitan, Area and at the National Observatory of Athens (NOA), typical of urban background conditions. More precisely, black carbon particles were concurrently measured using two sevenwavelength Aethalometers, whereas mixing ratios of $\mathrm{CO}$ were measured with an infrared absorption analyser at NOA and by wavelength-scanned cavity ring-down spectrometry at DEM.

The median BC concentrations were $528 \mathrm{ng} \mathrm{m}^{-3}$ at DEM and $1198 \mathrm{ng} \mathrm{m}^{-3}$ at NOA. In a similar way, median CO mixing ratios were $195 \mathrm{ppbv}$ at DEM and $324 \mathrm{ppbv}$ at NOA. These differences have been explained by the location of the two sites with respect to the proximity from sources and local atmospheric dynamics in the Athens valley. Both $\mathrm{BC}$ and $\mathrm{CO}$ displayed a clear bimodal diurnal pattern, in which morning peaks were observed due to morning inversion and rush hour traffic, while evening peaks were attributed to combustion sources (evening traffic rush hour, residential heating) combined with the effects of a shallow nocturnal boundary layer. The highest concentrations were observed during low wind speeds, suggesting that neither combustion products were related to regional transport but instead originated from sources within Athens.

Source apportionment of BC was carried out using a model based on the absorbance spectral differences of black carbon (related to fossil fuel) and brown carbon (related to biomass burning). Our results suggest that even though fossil fuel combustion is the major contributor to $\mathrm{BC}$ in $\mathrm{PM}_{10}$, wood burning makes an important contribution of about $30 \%$ to wintertime $\mathrm{BC}$ concentrations at both sites (on average $33 \%$ at DEM and $29 \%$ at NOA, respectively, but this difference lies within the uncertainty range of the calculations). $\mathrm{BC}$ from biomass burning displayed a clear unimodal diurnal pattern with the highest concentrations during night-time, confirming that its main source was local domestic heating.
As both datasets showed significant $\mathrm{BC}$ and $\mathrm{CO}$ correlations, we used observations of $\mathrm{CO}$ mixing ratios along with the fraction of $\mathrm{BC}_{\mathrm{wb}}$ and $\mathrm{BC}_{\mathrm{ff}}$ to quantify the percentage of observed $\mathrm{CO}$, which originates from fossil fuel and wood burning sources. This analysis led to the conclusion that the wood burning fraction of $\mathrm{CO}$ from local emissions represents on average $11-16 \%$ of total $\mathrm{CO}$ in Athens during wintertime. The method proposed here for the source apportionment of $\mathrm{CO}$ was compared to a previously reported method based on the $\mathrm{CO}-\mathrm{NO}_{x}$ ratios. From our results, it appears that the $\mathrm{CO}-\mathrm{NO}_{x}$ linear model overestimates the contribution of wood burning to $\mathrm{CO}$ concentrations, especially in environments characterized by aged air masses, likely due to the fact that the hypothesis of negligible photochemical loss of $\mathrm{NO}_{x}$ is not always met.

Data availability. Data from the Demokritos (DEM) monitoring station are regularly submitted at the EBAS WDCA database (ebas.nilu.no). However, the NASA-AMES template for the AE33 had only been introduced a very short time prior to this publication. These data will become available at the EBAS database as soon as possible. Until then, data are available upon request to the authors (mail to akalogridi@ipta.demokritos.gr and liakakou@noa.gr for DEM and NOA data respectively).

Competing interests. The authors declare that they have no conflict of interest.

Special issue statement. This article is part of the special issue "CHemistry and AeRosols Mediterranean EXperiments (ChArMEx) (ACP/AMT inter-journal SI)”.

Acknowledgements. Financial support from the European Union's EnTeC FP7 Capacities programme (REGPOT-2012-2013-1, FP7, ID: 316173) and the Horizon 2020 research and innovation programmes under grant agreements no. 654109 and no. 689443 is kindly acknowledged. Thanks are due to Jean Sciare for the loan of the AE-42 Aethalometer at Thiseio. We also acknowledge financial support by the KRIPIS/NSRF2007-2013 project and thank the NOA team (Vasileios Psilloglou and Maria Lianou Lianou) for the operation and maintenance of NOA's site at Thiseio. This study contributes to ChArMEx work package 1 on Emissions and Sources.

Edited by: François Dulac

Reviewed by: two anonymous referees

\section{References}

AIRUSE: Emission factors for biomass burning, Action B4, AIRUSE LIFE 11 ENV/ES/584, 2015. 
Albinet, A., Favez, O., Collet, S., Petit, J.-E., Nalin, F., Aujay, R., Verlhac, S., Dermingny, A., Fievet, A., Karsoski, N., Dubois, P., Golly, B., Besombes, J.-L., Pelletier, C., Sarda-Esteve, R., Gros, V., Bonnaire, N., and Sciare, J.: Emission dynamic from residential wood combustion: PM, BC, OM, VOCs and levoglucosan, in Handbook EAC, Milan, 2015.

Aleksandropoulou, V., Eleftheriadis, K., Diapouli, E., Torseth, K., and Lazaridis, M.: Assessing $\mathrm{PM}_{10}$ source reduction in urban agglomerations for air quality compliance, J. Environ. Monit., 14, 266-278, https://doi.org/10.1039/C1EM10673B, 2012.

Alves, C., Carvalho, A., and Pio, C.: Mass balance of organic carbon fractions in atmospheric aerosols, J. Geophys. Res.-Atmos., 107, 8345, https://doi.org/10.1029/2001JD000616, 2002.

Amanatidis, G. T., Papadopoulos, K. H., Bartzis, J. G., and Helmis, C. G.: Evidence of katabatic flows deduced from a $84 \mathrm{~m}$ meteorological tower in Athens, Greece, Bound.-Layer Meteorol., 58, 117-132, https://doi.org/10.1007/BF00120754, 1992.

Andreae, M. O. and Gelencsér, A.: Black carbon or brown carbon? The nature of light-absorbing carbonaceous aerosols, Atmos. Chem. Phys., 6, 3131-3148, https://doi.org/10.5194/acp-63131-2006, 2006.

Bond, T. C., Doherty, S. J., Fahey, D. W., Forster, P. M., Berntsen, T., DeAngelo, B. J., Flanner, M. G., Ghan, S., Kärcher, B., Koch, D., Kinne, S., Kondo, Y., Quinn, P. K., Sarofim, M. C., Schultz, M. G., Schulz, M., Venkataraman, C., Zhang, H., Zhang, S., Bellouin, N., Guttikunda, S. K., Hopke, P. K., Jacobson, M. Z., Kaiser, J. W., Klimont, Z., Lohmann, U., Schwarz, J. P., Shindell, D., Storelvmo, T., Warren, S. G., and Zender, C. S.: Bounding the role of black carbon in the climate system: A scientific assessment, J. Geophys. Res.-Atmos., 118, 5380-5552, https://doi.org/10.1002/jgrd.50171, 2013.

Chaloulakou, A., Kassomenos, P., Grivas, G., and Spyrellis, N.: Particulate matter and black smoke concentration levels in central Athens, Greece, Environ. Int., 31, 651-659, https://doi.org/10.1016/j.envint.2004.11.001, 2005.

Cohen, A. J., Anderson, H. R., Ostro, B., Pandey, K. D., Krzyzanowski, M., Künzli, N., Gutschmidt, K., Pope III, C. A., Romieu, I., Samet, J. M. and Smith, K. R.: Urban air pollution, Comp. Quantif. Health Risks, 2, 1353-1433, 2004.

Denier van der Gon, H. A. C., Bergström, R., Fountoukis, C., Johansson, C., Pandis, S. N., Simpson, D., and Visschedijk, A. J. H.: Particulate emissions from residential wood combustion in Europe - revised estimates and an evaluation, Atmos. Chem. Phys., 15, 6503-6519, https://doi.org/10.5194/acp15-6503-2015, 2015.

Diapouli, E., Popovicheva, O., Kistler, M., Vratolis, S., Persiantseva, N., Timofeev, M., Kasper-Giebl, A., and Eleftheriadis, K.: Physicochemical characterization of aged biomass burning aerosol after long-range transport to Greece from large scale wildfires in Russia and surrounding regions, Summer 2010, Atmos. Environ., 96 (Supplement C), 393-404, https://doi.org/10.1016/j.atmosenv.2014.07.055, 2014.

Diapouli, E., Manousakas, M., Vratolis, S., Vasilatou, V., Maggos, T., Saraga, D., Grigoratos, T., Argyropoulos, G., Voutsa, D., Samara, C., and Eleftheriadis, K.: Evolution of air pollution source contributions over one decade, derived by $\mathrm{PM}_{10}$ and $\mathrm{PM}_{2.5}$ source apportionment in two metropolitan urban areas in Greece, Atmos. Environ., 164, 416-430, https://doi.org/10.1016/j.atmosenv.2017.06.016, 2017a.
Diapouli, E., Kalogridis, A.-C., Markantonaki, C., Vratolis, S., Fetfatzis, P., Colombi, C., and Eleftheriadis, K.: Annual Variability of Black Carbon Concentrations Originating from Biomass and Fossil Fuel Combustion for the Suburban Aerosol in Athens, Greece, Atmosphere, 8, 234, https://doi.org/10.3390/atmos8120234, 2017b.

Drinovec, L., Močnik, G., Zotter, P., Prévôt, A. S. H., Ruckstuhl, C., Coz, E., Rupakheti, M., Sciare, J., Müller, T., Wiedensohler, A., and Hansen, A. D. A.: The "dual-spot" Aethalometer: an improved measurement of aerosol black carbon with realtime loading compensation, Atmos. Meas. Tech., 8, 1965-1979, https://doi.org/10.5194/amt-8-1965-2015, 2015.

Eleftheriadis, K., Balis, D., Ziomas, I. C., ColBeck, I., and Manalis, N.: Atmospheric aerosol and gaseous species in Athens, Greece, Atmos. Environ., 32, 2183-2191, 1998.

Eleftheriadis, K., Ochsenkuhn, K. M., Lymperopoulou, T., Karanasiou, A., Razos, P., and Ochsenkuhn-Petropoulou, M.: Influence of local and regional sources on the observed spatial and temporal variability of size resolved atmospheric aerosol mass concentrations and water-soluble species in the Athens metropolitan area, Atmos. Environ., 97, 252-261, 2014.

Favez, O., Cachier, H., Sciare, J., Sarda-Estève, R., and Martinon, L.: Evidence for a significant contribution of wood burning aerosols to $\mathrm{PM}_{2.5}$ during the winter season in Paris, France, Atmos. Environ., 43, 3640-3644, https://doi.org/10.1016/j.atmosenv.2009.04.035, 2009.

Fourtziou, L., Liakakou, E., Stavroulas, I., Theodosi, C., Zarmpas, P., Psiloglou, B., Sciare, J., Maggos, T., Bairachtari, K., Bougiatioti, A., Gerasopoulos, E., Sarda-Estève, R., Bonnaire, N., and Mihalopoulos, N.: Multi-tracer approach to characterize domestic wood burning in Athens (Greece) during wintertime, Atmos. Environ., 148 (Supplement C), 89-101, https://doi.org/10.1016/j.atmosenv.2016.10.011, 2017.

Fujita, E. M., Croes, B. E., Bennett, C. L., Lawson, D. R., Lurmann, F. W., and Main, H. H.: Comparison of Emission Inventory and Ambient Concentration Ratios of $\mathrm{CO}, \mathrm{NMOG}$, and $\mathrm{NO}_{x}$ in California's South Coast Air Basin, J. Air Waste Manag. Assoc., 42, 264-276, https://doi.org/10.1080/10473289.1992.10466989, 1992.

Fuller, G. W., Tremper, A. H., Baker, T. D., Yttri, K. E., and Butterfield, D.: Contribution of wood burning to $\mathrm{PM}_{10}$ in London, Atmos. Environ., 87, 87-94, https://doi.org/10.1016/j.atmosenv.2013.12.037, 2014.

Giannoni, M., Martellini, T., Bubba, M. D., Gambaro, A., Zangrando, R., Chiari, M., Lepri, L., and Cincinelli, A.: The use of levoglucosan for tracing biomass burning in $\mathrm{PM}_{2.5}$ samples in Tuscany (Italy), Environ. Pollut., 167 (Supplement C), 7-15, https://doi.org/10.1016/j.envpol.2012.03.016, 2012.

Gonçalves, C., Alves, C., Fernandes, A. P., Monteiro, C., Tarelho, L., Evtyugina, M., and Pio, C.: Organic compounds in $\mathrm{PM}_{2.5}$ emitted from fireplace and woodstove combustion of typical Portuguese wood species, Atmos. Environ., 45, 4533-4545, https://doi.org/10.1016/j.atmosenv.2011.05.071, 2011.

Gratsea, M., Liakakou, E., Mihalopoulos, N., Adamopoulos, A., Tsilibari, E., and Gerasopoulos, E.: The combined effect of reduced fossil fuel consumption and increasing biomass combustion on Athens' air quality, as inferred from long term CO measurements, Sci. Total Environ., 592, 115-123, https://doi.org/10.1016/j.scitotenv.2017.03.045, 2017. 
Grivas, G., Cheristanidis, S., and Chaloulakou, A.: Elemental and organic carbon in the urban environment of Athens. Seasonal and diurnal variations and estimates of secondary organic carbon, Sci. Total Environ., 414, 535-545, https://doi.org/10.1016/j.scitotenv.2011.10.058, 2012.

Gros, V., Jöckel, P., Brenninkmeijer, C. A. M., Röckmann, T., Meinhardt, F., and Graul, R.: Characterization of pollution events observed at Schauinsland, Germany, using CO and its stable isotopes, Atmos. Environ., 36, 2831-2840, https://doi.org/10.1016/S1352-2310(02)00144-9, 2002.

Herich, H., Hueglin, C., and Buchmann, B.: A 2.5 year's source apportionment study of black carbon from wood burning and fossil fuel combustion at urban and rural sites in Switzerland, Atmos. Meas. Tech., 4, 1409-1420, https://doi.org/10.5194/amt-4-14092011, 2011.

Hitzenberger, R. and Tohno, S.: Comparison of black carbon (BC) aerosols in two urban areas - concentrations and size distributions, Atmos. Environ., 35, 2153-2167, https://doi.org/10.1016/S1352-2310(00)00480-5, 2001.

Hitzenberger, R., Petzold, A., Bauer, H., Ctyroky, P., Pouresmaeil, P., Laskus, L., and Puxbaum, H.: Intercomparison of Thermal and Optical Measurement Methods for Elemental Carbon and Black Carbon at an Urban Location, Environ. Sci. Technol., 40, 6377-6383, https://doi.org/10.1021/es051228v, 2006.

Hoffer, A., Gelencsér, A., Guyon, P., Kiss, G., Schmid, O., Frank, G. P., Artaxo, P., and Andreae, M. O.: Optical properties of humiclike substances (HULIS) in biomass-burning aerosols, Atmos. Chem. Phys., 6, 3563-3570, https://doi.org/10.5194/acp-6-35632006, 2006.

Invernizzi, G., Ruprecht, A., Mazza, R., De Marco, C., Močnik, G., Sioutas, C., and Westerdahl, D.: Measurement of black carbon concentration as an indicator of air quality benefits of traffic restriction policies within the ecopass zone in Milan, Italy, Atmos. Environ., 45, 3522-3527, https://doi.org/10.1016/j.atmosenv.2011.04.008, 2011.

Kalabokas, P. D., Viras, L. G., and Repapis, C. C.: Analysis of the 11-year record (1987-1997) of air pollution measurements in Athens, Greece. Part I: Primary air pollutants, Glob. Nest Int. J., 1, 157-168, 1999.

Kanakidou, M., Mihalopoulos, N., Kindap, T., Im, U., Vrekoussis, M., Gerasopoulos, E., Dermitzaki, E., Unal, A., Kocak, M., Markakis, K., Melas, D., Kouvarakis, G., Youssef, A. F., Richter, A., Hatzianastassiou, N., Hilboll, A., Ebojie, F., Wittrock, F., von Savigny, C., Burrows, J. P., Ladstaetter-Weissenmayer, A., and Moubasher, H.: Megacities as hot spots of air pollution in the East Mediterranean, Atmos. Environ., 45, 1223-1235, https://doi.org/10.1016/j.atmosenv.2010.11.048, 2011.

Kassomenos, P. A. and Koletsis, I. G.: Seasonal variation of the temperature inversions over Athens, Greece, Int. J. Climatol., 25, 1651-1663, https://doi.org/10.1002/joc.1188, 2005.

Kato, S., Akimoto, H., Bräunlich, M., Röckmann, T., and Brenninkmeijer, C. A. M.: Measurements of stable carbon and oxygen isotopic compositions of $\mathrm{CO}$ in automobile exhausts and ambient air from semi-urban Mainz, Germany, Geochem. J., 33, 73-77, https://doi.org/10.2343/geochemj.33.73, 1999.

Kavouridis, K.: Lignite industry in Greece within a world context: Mining, energy supply and environment, Energ. Policy, 36, 1257-1272, 2008.
Kocbach Bølling, A., Pagels, J., Yttri, K. E., Barregard, L., Sallsten, G., Schwarze, P. E., and Boman, C.: Health effects of residential wood smoke particles: the importance of combustion conditions and physicochemical particle properties, Part. Fibre Toxicol., 6, p. 29, https://doi.org/10.1186/1743-8977-6-29, 2009.

Kondo, Y., Komazaki, Y., Miyazaki, Y., Moteki, N., Takegawa, N., Kodama, D., Deguchi, S., Nogami, M., Fukuda, M., Miyakawa, T., Morino, Y., Koike, M., Sakurai, H., and Ehara, K.: Temporal variations of elemental carbon in Tokyo, J. Geophys. Res.Atmos., 111, D12205, https://doi.org/10.1029/2005JD006257, 2006.

Laborde, M., Crippa, M., Tritscher, T., Jurányi, Z., Decarlo, P. F., Temime-Roussel, B., Marchand, N., Eckhardt, S., Stohl, A., Baltensperger, U., Prévôt, A. S. H., Weingartner, E., and Gysel, M.: Black carbon physical properties and mixing state in the European megacity Paris, Atmos. Chem. Phys., 13, 5831-5856, https://doi.org/10.5194/acp-13-5831-2013, 2013.

Nalin, F.: PAHs and their nitrated and oxygenated derivatives (NPAHs and OPAHs) emitted by wood combustion: Original analytical development and study of their evolution from emission point to ambient air, $\mathrm{PhD}$ dissertation, Universita degli studi di torino, Universita degli studi di Torino, July, 2014.

Ostro, B., Hu, J., Goldberg, D., Reynolds, P., Hertz, A., Bernstein, L., and Kleeman, M. J.: Associations of mortality with long-term exposures to fine and ultrafine particles, species and sources: results from the California Teachers Study Cohort, Environ. Health Perspect., 123, 549-556, https://doi.org/10.1289/ehp.1408565, 2015.

Paglione, M., Saarikoski, S., Carbone, S., Hillamo, R., Facchini, M. C., Finessi, E., Giulianelli, L., Carbone, C., Fuzzi, S., Moretti, F., Tagliavini, E., Swietlicki, E., Eriksson Stenström, K., Prévôt, A. S. H., Massoli, P., Canaragatna, M., Worsnop, D., and Decesari, S.: Primary and secondary biomass burning aerosols determined by proton nuclear magnetic resonance (1H-NMR) spectroscopy during the 2008 EUCAARI campaign in the Po Valley (Italy), Atmos. Chem. Phys., 14, 5089-5110, https://doi.org/10.5194/acp14-5089-2014, 2014.

Pan, X. L., Kanaya, Y., Wang, Z. F., Taketani, F., Tanimoto, H., Irie, H., Takashima, H., and Inomata, S.: Emission ratio of carbonaceous aerosols observed near crop residual burning sources in a rural area of the Yangtze River Delta Region, China, J. Geophys. Res.-Atmos., 117, D22304, https://doi.org/10.1029/2012JD018357, 2012.

Paraskevopoulou, D., Liakakou, E., Gerasopoulos, E., Theodosi, C., and Mihalopoulos, N.: Long-term characterization of organic and elemental carbon in the $\mathrm{PM}_{2.5}$ fraction: the case of Athens, Greece, Atmos. Chem. Phys., 14, 13313-13325, https://doi.org/10.5194/acp-14-13313-2014, 2014.

Paraskevopoulou, D., Liakakou, E., Gerasopoulos, E., and Mihalopoulos, N.: Sources of atmospheric aerosol from longterm measurements (5 years) of chemical composition in Athens, Greece, Sci. Total Environ., 527-528, 165-178, https://doi.org/10.1016/j.scitotenv.2015.04.022, 2015.

Petit, J.-E., Favez, O., Sciare, J., Canonaco, F., Croteau, P., Močnik, G., Jayne, J., Worsnop, D., and Leoz-Garziandia, E.: Submicron aerosol source apportionment of wintertime pollution in Paris, France by double positive matrix factorization (PMF2) using an aerosol chemical speciation monitor (ACSM) and a multi- 
wavelength Aethalometer, Atmos. Chem. Phys., 14, 1377313787, https://doi.org/10.5194/acp-14-13773-2014, 2014.

Petzold, A., Ogren, J. A., Fiebig, M., Laj, P., Li, S.-M., Baltensperger, U., Holzer-Popp, T., Kinne, S., Pappalardo, G., Sugimoto, N., Wehrli, C., Wiedensohler, A., and Zhang, X.-Y.: Recommendations for reporting "black carbon" measurements, Atmos. Chem. Phys., 13, 8365-8379, https://doi.org/10.5194/acp13-8365-2013, 2013.

Ravindra, K., Wauters, E., Tyagi, S. K., Mor, S., and Grieken, R. V.: Assessment of Air Quality After the Implementation of Compressed Natural Gas (CNG) as Fuel in Public Transport in Delhi, India, Environ. Monit. Assess., 115, 405-417, https://doi.org/10.1007/s10661-006-7051-5, 2006.

Reche, C., Querol, X., Alastuey, A., Viana, M., Pey, J., Moreno, T., Rodríguez, S., González, Y., Fernández-Camacho, R., de la Rosa, J., Dall'Osto, M., Prévôt, A. S. H., Hueglin, C., Harrison, R. M., and Quincey, P.: New considerations for PM, Black Carbon and particle number concentration for air quality monitoring across different European cities, Atmos. Chem. Phys., 11, 6207-6227, https://doi.org/10.5194/acp-11-6207-2011, 2011.

Rodríguez, S. and Cuevas, E.: The contributions of "minimum primary emissions" and "new particle formation enhancements" to the particle number concentration in urban air, J. Aerosol Sci., 38, 1207-1219, https://doi.org/10.1016/j.jaerosci.2007.09.001, 2007.

Saffari, A., Daher, N., Samara, C., Voutsa, D., Kouras, A., Manoli, E., Karagkiozidou, O., Vlachokostas, C., Moussiopoulos, N., Shafer, M. M., and others: Increased biomass burning due to the economic crisis in Greece and its adverse impact on wintertime air quality in Thessaloniki, Environ. Sci. Technol., 47, 1331313320, 2013.

Sandradewi, J., Prévôt, A. S. H., Szidat, S., Perron, N., Alfarra, M. R., Lanz, V. A., Weingartner, E., and Baltensperger, U.: Using Aerosol Light Absorption Measurements for the Quantitative Determination of Wood Burning and Traffic Emission Contributions to Particulate Matter, Environ. Sci. Technol., 42, 33163323, https://doi.org/10.1021/es702253m, 2008.

Saurer, M., Prévôt, A. S. H., Dommen, J., Sandradewi, J., Baltensperger, U., and Siegwolf, R. T. W.: The influence of traffic and wood combustion on the stable isotopic composition of carbon monoxide, Atmospheric Chem. Phys., 9, 3147-3161, https://doi.org/10.5194/acp-9-3147-2009, 2009.

Sciare, J., d'Argouges, O., Sarda-Estève, R., Gaimoz, C., Dolgorouky, C., Bonnaire, N., Favez, O., Bonsang, B., and Gros, V.: Large contribution of water-insoluble secondary organic aerosols in the region of Paris (France) during wintertime, J. Geophys. Res.-Atmos., 116, D22203, https://doi.org/10.1029/2011JD015756, 2011.

Seinfeld, J. H. and Pandis, S. N.: Atmospheric chemistry and physics: from air pollution to climate change, John Wiley \& Sons, p. 46, 2012.

Theodosi, C., Grivas, G., Zarmpas, P., Chaloulakou, A., and Mihalopoulos, N.: Mass and chemical composition of sizesegregated aerosols (PM1, $\mathrm{PM}_{2.5}, \mathrm{PM}_{10}$ ) over Athens, Greece: local versus regional sources, Atmos. Chem. Phys., 11, 1189511911, https://doi.org/10.5194/acp-11-11895-2011, 2011.

Tombrou, M., Dandou, A., Helmis, C., Akylas, E., Angelopoulos, G., Flocas, H., Assimakopoulos, V., and Soulakellis, N.: Model evaluation of the atmospheric boundary layer and mixed-layer evolution, Bound.-Layer Meteorol., 124, 61-79, https://doi.org/10.1007/s10546-006-9146-5, 2007.

Triantafyllou, E., Diapouli, E., Tsilibari, E. M., Adamopoulos, A. D., Biskos, G., and Eleftheriadis, K.: Assessment of factors influencing PM mass concentration measured by gravimetric \& beta attenuation techniques at a suburban site, Atmos. Environ., 131, 409-417, https://doi.org/10.1016/j.atmosenv.2016.02.010, 2016.

Verma, R. L., Sahu, L. K., Kondo, Y., Takegawa, N., Han, S., Jung, J. S., Kim, Y. J., Fan, S., Sugimoto, N., Shammaa, M. H., Zhang, Y. H., and Zhao, Y.: Temporal variations of black carbon in Guangzhou, China, in summer 2006, Atmos. Chem. Phys., 10, 6471-6485, https://doi.org/10.5194/acp-10-6471-2010, 2010.

Vrekoussis, M., Richter, A., Hilboll, A., Burrows, J. P., Gerasopoulos, E., Lelieveld, J., Barrie, L., Zerefos, C., and Mihalopoulos, N.: Economic crisis detected from space: Air quality observations over Athens/Greece, Geophys. Res. Lett., 40, 458-463, https://doi.org/10.1002/grl.50118, 2013.

Wahlina, P., Palmgren, F., and Van Dingenen, R.: Experimental studies of ultrafine particles in streets and the relationship to traffic, Atmos. Environ., 35, S63-S69, https://doi.org/10.1016/S1352-2310(00)00500-8, 2001.

Wang, Q., Liu, S., Zhou, Y., Cao, J., Han, Y., Ni, H., Zhang, N., and Huang, R.: Characteristics of Black Carbon Aerosol during the Chinese Lunar Year and Weekdays in Xi' an, China, Atmosphere, 6, 195-208, https://doi.org/10.3390/atmos6020195, 2015.

Weingartner, E., Saathoff, H., Schnaiter, M., Streit, N., Bitnar, B., and Baltensperger, U.: Absorption of light by soot particles: determination of the absorption coefficient by means of aethalometers, J. Aerosol Sci., 34, 1445-1463, https://doi.org/10.1016/S0021-8502(03)00359-8, 2003.

Yang, M., Howell, S. G., Zhuang, J., and Huebert, B. J.: Attribution of aerosol light absorption to black carbon, brown carbon, and dust in China - interpretations of atmospheric measurements during EAST-AIRE, Atmos. Chem. Phys., 9, 2035-2050, https://doi.org/10.5194/acp-9-2035-2009, 2009.

Zanatta, M., Gysel, M., Bukowiecki, N., Müller, T., Weingartner, E., Areskoug, H., Fiebig, M., Yttri, K. E., Mihalopoulos, N., Kouvarakis, G., Beddows, D., Harrison, R. M., Cavalli, F., Putaud, J. P., Spindler, G., Wiedensohler, A., Alastuey, A., Pandolfi, M., Sellegri, K., Swietlicki, E., Jaffrezo, J. L., Baltensperger, U., and Laj, P.: A European aerosol phenomenology-5: Climatology of black carbon optical properties at 9 regional background sites across Europe, Atmos. Environ., 145, 346-364, https://doi.org/10.1016/j.atmosenv.2016.09.035, 2016.

Zhang, Q. J., Beekmann, M., Drewnick, F., Freutel, F., Schneider, J., Crippa, M., Prevot, A. S. H., Baltensperger, U., Poulain, L., Wiedensohler, A., Sciare, J., Gros, V., Borbon, A., Colomb, A., Michoud, V., Doussin, J.-F., Denier van der Gon, H. A. C., Haeffelin, M., Dupont, J.-C., Siour, G., Petetin, H., Bessagnet, B., Pandis, S. N., Hodzic, A., Sanchez, O., Honoré, C., and Perrussel, O.: Formation of organic aerosol in the Paris region during the MEGAPOLI summer campaign: evaluation of the volatilitybasis-set approach within the CHIMERE model, Atmospheric Chem. Phys., 13, 5767-5790, https://doi.org/10.5194/acp-135767-2013, 2013.

Zotter, P., Herich, H., Gysel, M., El-Haddad, I., Zhang, Y., Močnik, G., Hüglin, C., Baltensperger, U., Szidat, S., and Prévôt, A. S. H.: Evaluation of the absorption Ångström exponents for traffic and wood burning in the Aethalometer-based source apportion- 
ment using radiocarbon measurements of ambient aerosol, Atmos. Chem. Phys., 17, 4229-4249, https://doi.org/10.5194/acp17-4229-2017, 2017. 